\title{
The end of the African humid period as seen by a transient comprehensive Earth system model simulation of the last 8000 years
}

\author{
Anne Dallmeyer ${ }^{1}$, Martin Claussen ${ }^{1,2}$, Stephan J. Lorenz ${ }^{3}$, and Timothy Shanahan ${ }^{4}$ \\ ${ }^{1}$ The Land in the Earth System, Max Planck Institute for Meteorology, Bundesstrasse 53, 20146 Hamburg, Germany \\ ${ }^{2}$ Meteorological Institute, Centrum für Erdsystemforschung und Nachhaltigkeit (CEN), Universität Hamburg, \\ Bundesstrasse 55, 20146 Hamburg, Germany \\ ${ }^{3}$ The Ocean in the Earth System, Max Planck Institute for Meteorology, Bundesstrasse 53, 20146 Hamburg, Germany \\ ${ }^{4}$ The University of Texas at Austin, Department of Geological Sciences, 1 University Station C9000, \\ Austin, Texas 78712, USA
}

Correspondence: Anne Dallmeyer (anne.dallmeyer@mpimet.mpg.de)

Received: 12 July 2019 - Discussion started: 30 July 2019

Revised: 30 October 2019 - Accepted: 15 November 2019 - Published: 15 January 2020

\begin{abstract}
Enhanced summer insolation during the early and mid-Holocene drove increased precipitation and widespread expansion of vegetation across the Sahara during the African humid period (AHP). While changes in atmospheric dynamics during this time have been a major focus of palaeoclimate modelling efforts, the transient nature of the shift back to the modern desert state at the end of this period is less well understood. Reconstructions reveal a spatially and temporally complex end of the AHP, with an earlier end in the north than in the south and in the east than in the west. Some records suggest a rather abrupt end, whereas others indicate a gradual decline in moisture availability. Here we investigate the end of the AHP based on a transient simulation of the last 7850 years with the comprehensive Earth system model MPI-ESM1.2. The model largely reproduces the time-transgressive end of the AHP evident in proxy data, and it indicates that it is due to the regionally varying dynamical controls on precipitation. The impact of the main rain-bringing systems, i.e. the summer monsoon and extratropical troughs, varies spatially, leading to heterogeneous seasonal rainfall cycles that impose regionally different responses to the Holocene insolation decrease. An increase in extratropical troughs that interact with the tropical mean flow and transport moisture to the western Sahara during the midHolocene delays the end of the AHP in that region. Along the coast, this interaction maintains humid conditions for a
\end{abstract}

longer time than further inland. Drying in this area occurs when this interaction becomes too weak to sustain precipitation. In the lower latitudes of west Africa, where the rainfall is only influenced by the summer monsoon dynamics, the end of the AHP coincides with the retreat of the monsoonal rain belt. The model results clearly demonstrate that non-monsoonal dynamics can also play an important role in forming the precipitation signal and should therefore not be neglected in analyses of north African rainfall trends.

\section{Introduction}

Periodic variations in the Earth's orbit around the sun trigger the alternation of dry and humid phases in the north African Sahara (Kutzbach, 1981; deMenocal and Tierney, 2012). The main driver of these changes is the precession of the equinoxes, which leads to a shift in the time of perihelion and thus alters the seasonal insolation. Wet conditions return roughly every 20000 years in the Sahara (Skonieczny et al., 2019), as a consequence of increased summertime insolation. The last wet phase was established during the early- and mid-Holocene and is commonly called the "green Sahara" or "African humid period" (AHP, Claussen et al., 2017). The climate and environmental changes during that time are well-documented by diverse proxies from terrestrial and marine palaeorecords. Pollen-based vegetation reconstructions 
indicate a widespread northward migration of the steppe and savanna biomes with tropical plants occurring as far as $23^{\circ} \mathrm{N}$ during the AHP (e.g. Jolly et al., 1998; Hély et al., 2014). The Sahara was nearly completely covered by vegetation, supported by substantially increased rainfall (e.g. Hoelzmann et al., 2000; Peyron et al., 2006; Bartlein et al., 2011; Tierney et al., 2017). Permanent lakes spread over the entire north African continent and reached at least up to $28^{\circ} \mathrm{N}$ (COHMAP Members, 1988; Street-Perrott et al., 1989; Hoelzmann et al., 1998, Tierney et al., 2011; Lézine et al., 2011). Sediment cores taken off the northwest African coast characterize the AHP as an interval of low atmospheric mineral dust fluxes from the Sahara, reflecting the overall increase in vegetation and lake area in this region (deMenocal et al., 2000; Adkins et al., 2006; McGee et al., 2013). More humid conditions and the expansion of vegetation also favoured the migration of human populations and cultural development across north Africa (Hoelzmann et al., 2002; Kuper and Kröpelin, 2006).

These changes in environmental conditions are closely related to an enhanced west African summer monsoon system, which was driven by an increased land-ocean thermal gradient resulting from increased boreal summer insolation (Kutzbach, 1981). Furthermore, a number of modelling studies have suggested that precession-driven changes in summer insolation not only intensified the monsoon but also directly influenced the northward extent of the monsoon rain belt (e.g. Tuenter et al., 2003; Braconnot et al., 2008; Bosmans et al., 2014). However, the effects of summer insolation changes were not limited to changes in the monsoon westerly winds (e.g. Su and Neelin, 2005). For example, the African easterly jet (AEJ), a strong wind band with core around $600 \mathrm{hPa}$ and $15^{\circ} \mathrm{N}$ during present-day summer, forms due to the strong vertical easterly shear induced by the temperature and soil moisture gradients between the Sahara and lower latitudes (Cook, 1999). The weakening of these gradients during early- and mid-Holocene led to a deceleration and northward shift of the AEJ, enhancing the moisture content over north Africa (Patricola and Cook, 2007; Bosmans et al., 2012; Rachmayani et al., 2015). The AEJ plays an important role for summer rainfall generation in the Sahel and Sahara. Due to the barotropic-baroclinic instability of the jet (Wu et al., 2012), synoptic disturbances are initiated and organized along the jet, the so called African easterly waves (AEWs). Within the AEWs, squall lines and mesoscale convective systems form, which are responsible for most of the annual precipitation in large parts of northern Africa (Nicholson and Grist, 2003; Skinner and Diffenbaugh, 2013, and references therein; Janiga and Thorncroft, 2016). The dust reduction and the decrease in AEJ speed resulted in less AEW activity during early and mid-Holocene, albeit the latent heat and convection was enhanced (Gaetani et al., 2017). In the upper troposphere, the increase in summer insolation modified the large-sale atmospheric temperature gradients and led to a northward shift of the subpolar and subtropical westerly jet and an intensification of the tropical easterly jet (TEJ) at early- and mid-Holocene (Gaetani et al., 2017). How changes in the TEJ affect the north African rainfall is currently under discussion. On interannual and decadal timescales, Sahel rainfall and TEJ intensity are positively correlated (Grist and Nicholson, 2001; Nicholson, 2009). This correlation is not present on intraseasonal and synoptic timescales (Lemburg et al., 2019).

A number of atmospheric modelling studies have shown that the pure insolation forcing is not sufficient to reproduce the reconstructed rainfall increase in north Africa (e.g. Joussaume et al., 1999; Braconnot et al., 2000). Feedbacks between the ocean, the land surface and the atmosphere substantially amplify the rainfall response (e.g. Claussen and Gayler, 1997; Kutzbach and Liu, 1997; Zhao et al., 2005; Braconnot et al., 2007; Vamborg et al., 2011; Swann et al., 2014; Rachmayani et al., 2015). Nevertheless, fully coupled Earth system models still underestimate the intensification and northward expansion of the rain belt compared with proxy data during the AHP (e.g. Braconnot et al., 2012; Harrison et al., 2014; Perez-Sanz et al., 2014). The suggested causes for this mismatch are diverse. Besides shortcomings in the parametrization and representation of the mesoscale (subgrid-scale) convection and biases in the ocean temperature (Roehrig et al., 2013), the poor representation of land surface properties (e.g. Levis et al., 2004; Vamborg et al., 2011), lake and wetland expansion, and their feedbacks on the monsoon system have been proposed to explain model-data discrepancies (Krinner et al., 2012). A possible influence of changes in the dust flux is controversially discussed (e.g. Pausata et al., 2016; Thompson et al., 2019). However, to date, all of these shortcomings have been discussed primarily in the context of changes in summer monsoon dynamics. Changes in the atmospheric circulation outside the monsoon season are often ignored. Analyses of the current precipitation distribution show that a large proportion of precipitation in the Sahara is associated with extratropical troughs during spring and autumn that penetrate in the lower latitudes and transport moisture into the Sahara in the form of concentrated water vapour plumes, the so-called tropical plumes (e.g. Knippertz, 2003; Fröhlich et al., 2013). Although these phenomena occur only sporadically in present-day climate, they induce locally heavy rainfall, particularly in times (e.g. during late summer) when the monsoon rain belt (the moisture supplying system) is still close to its most northerly position, while the subtropical jet is moved back to the south (Knippertz, 2003). It is possible, given the changes in large-scale atmospheric circulation during the mid-Holocene, that tropical plumes may have played a more significant role in the increase in Saharan precipitation at that time (Geb, 2000; Kutzbach et al., 2014). For example, Skinner and Poulsen (2016) found an increase in (autumn season) tropical plume activity during the early- and mid-Holocene and argued that atmospheric conditions were particularly favourable for the extratropical-tropical interac- 
tions (ETI) at mid-Holocene because solar insolation peaked in the early autumn. This interaction can act as an amplifier for the insolation-induced and monsoon-related variations in Saharan precipitation.

Over the Holocene, summertime insolation decreased and the monsoon retreated southward resulting in the end of the mid-Holocene humid phase over large parts of the continent. A great deal of research has been focused on understanding the differences in the relative abruptness of the drying at the end of the AHP (e.g. Claussen et al., 1999; Renssen et al., 2003; Liu et al., 2006, 2007; Collins et al., 2017), which appears to have varied substantially across north Africa (e.g. deMenocal et al., 2000; Kröpelin et al., 2008). However, it has recently been suggested that the onset of drying also varied spatially, with an earlier end of the AHP in the Sahara than in the lower latitudes and an earlier end in the eastern part than in the western part of north Africa (Shanahan et al., 2015). These differences are seemingly incongruous with a simple southward contraction of the monsoon rain belt, and they may reflect the influence of other regionally important precipitation-generating processes. To address this question here, we investigate the end of the AHP in a transient global simulation of the last 7850 years (Bader et al., 2019) that was performed using the comprehensive Earth system model MPI-ESM1.2. This simulation includes for the first time not only the orbital, atmospheric greenhouse gas or land-use forcing, but also forcings on shorter timescales (volcanic eruptions, spectral solar irradiance changes). The main focus of this study is the analysis of the main atmospheric circulation changes driving the asynchronous termination of the AHP. The assessment of the abruptness of the transition to the dry state is covered by a follow-up study.

\section{Methods}

\subsection{The model MPI-ESM1.2}

In this study a transient simulation (Bader et al., 2019) of the last 7850 years was performed with the comprehensive Earth system model MPI-ESM1.2 (Mauritsen et al., 2019). The model consists of the atmospheric general circulation model ECHAM6.3 (Stevens et al., 2013) coupled to the landsurface scheme JSBACH3 (Reick et al., 2013) and the general circulation model of the ocean MPIOM (Jungclaus et al., 2013). MPIOM incorporates the global ocean biogeochemistry model HAMOCC (Ilyina et al., 2013). JSBACH3 includes the soil carbon model YASSO (Goll et al., 2015), dynamic vegetation (Brovkin et al., 2009), a five-layer hydrology scheme (Hagemann and Stacke, 2015), and a dynamic background albedo scheme, which has previously been shown to improve the representation of Holocene precipitation change in north Africa (Vamborg et al., 2011). Natural vegetation is represented by eight different plant functional types (PFTs) (tropical or temperate evergreen or deciduous trees, rain-green and cold resistant shrubs, $\mathrm{C}_{3}$ and
$\mathrm{C}_{4}$ grasses), which can in principle coexist in each grid cell as the model uses a tiling approach. The occurrence of each PFT is constrained by temperature thresholds representing their respective bioclimatic tolerance. The fractional cover of each PFT is by and large determined by the relative differences in annual net primary productivity (NPP) between the PFTs, which - among other factors - depends on the moisture ability and requirement of the plants. The establishment of PFTs is furthermore reduced by disturbances and weighted by the inverse of the PFT-specific lifetime. Woody PFTs are generally favoured over grass, but, in regions with frequent disturbances or bioclimatic conditions near the thresholds, shrubs or even grass may win the competition as they can recover more quickly than trees. For each grid cell, a bare soil fraction (BSF) is considered in addition to the vegetated area, which represents the seasonal and permanently unvegetated ground. Their fraction is calculated via the relation of maximum carbon storage in the pool for living tissues to the carbon actually stored in this pool by the NPP, representing the need of plants for a certain amount of carbon to build up their leaves so that they can function properly. If the filling of the pool is not sufficient for all PFTs, plants cannot grow and the grid cell is mainly non-vegetated. Thus, simulated changes in vegetation cover can be attributed to bioclimatic shifts (i.e. temperature changes), changes in plant productivity (related to precipitation), or changes in the frequency of disturbances. More details and information about the dynamic vegetation module is given in Brovkin et al. (2009) and Reick et al. (2013).

Through the inclusion of the subsystem models JSBACH and HAMOCC, the full carbon cycle is enabled in MPIESM. However, the atmospheric $\mathrm{CO}_{2}$ concentration is prescribed in the experiments regarded here so that the carbon cycle is not fully interactive.

The atmosphere and land model was configured with a spectral resolution of T63 (approx. $200 \mathrm{~km}$ on a Gaussian grid) with 47 levels in the vertical. The ocean model was employed in the horizontal resolution GR15 (i.e. $256 \times 220$ on a bipolar grid, 12 to $180 \mathrm{~km}$ ) with 64 vertical levels.

Since we have decided to use the extensively tested CMIP5 version of the ECHAM6 model for this long transient simulation, the indirect effect, or Twomey effect, of aerosols is not considered. The cloud droplet concentration and the emission of mineral dust is prescribed based on modern observation and does not vary with vegetation cover. Snapshots of Holocene simulations using the same ECHAM6 version, but including variable dust emission depending on changes in vegetation and lake cover, were done by Egerer et al. (2018).

\subsection{The transient simulation}

We conducted a "spin-down" simulation to capture the model's response to constant boundary conditions of the midHolocene climate. For this spin-down simulation, the model has been started from preindustrial climate, and vegetation 
conditions, and the external forcing mechanisms were kept constant to the values of the year $6000 \mathrm{BCE}$. The model ran more than 1000 years to reach quasi-equilibrium between the boundary conditions, climate and the carbon cycle. The transient simulation started from this equilibrium state and was run until preindustrial (PI) time (i.e. 1850 CE). For easier nomenclature, we define the early mid-Holocene time slice (further referred to as $8 \mathrm{ka}$ ) by the climatological mean of the first 100 years of this transient simulations (i.e. years 6000 5901 BCE) and the PI reference period by the climatological mean of the last 100 years of this simulations (i.e. year 1751$1850 \mathrm{CE})$. Accordingly, we define the mid-Holocene time slice $(6 \mathrm{ka})$ by the climatological mean of the years 4000 3901 BCE.

The transient simulation was performed by using the following forcings:

a. The orbital-induced insolation changes (Berger, 1978). These mainly impact the seasonal cycle of, for example, the atmospheric temperature and precipitation. At the start of the simulation, Northern Hemisphere summer insolation is near its maximum and declines gradually toward the present in association with the precession of the equinoxes. The seasonality reduces on the Northern Hemisphere and enhances on the Southern Hemisphere over the Holocene.

b. Methane, nitrous oxide, and carbon dioxide concentrations. These were inferred from ice core records (Fortunat Joos, personal communication, 2016; see Brovkin et al., 2019; Köhler, 2019). The difference in $\mathrm{CO}_{2}$ between start and end of the simulations is relatively small, amounting to approximately $20 \mathrm{ppm}$.

c. Stratospheric sulfate aerosol injections imitating volcanic eruptions. These were prescribed from the Easy Volcanic Aerosol (EVA) forcing generator (Toohey and Sigl, 2017). This forcing is based on data of the GISP2 Greenland ice core (Zielinski et al., 1996) only and is probably overestimated during some periods due to overloads by Icelandic volcanic eruptions (cf. Bader et al., 2019). Since the volcanic forcing has a minor effect on the vegetation in our simulation, we assume that our results and conclusions are not affected by this overestimated forcing.

d. Spectral solar irradiance forcing. This includes an extrapolated 11-year solar cycle based on sun-spot observation sets of far infrared, near-infrared, and visible radiation (Krivova et al., 2011).

e. New land-use data adopted from Hurtt et al. (2011). This forcing begins at $850 \mathrm{CE}$ with a linear transition period (1000 years) starting at $150 \mathrm{BCE}$ to slowly build up the land use.
Table 1. List of time slices used in this study. For the time slices marked with *, simulation has been restarted to produce daily output for 30 model years. Please notice that an interval of low variability had been chosen for these simulations; therefore, the time slice $7 \mathrm{ka}$ actually starts before $7 \mathrm{ka}$ (at model year 1961 instead of model year 2001). Please also notice that all means of theses time slices are based on 30 years only, while the means on $8 \mathrm{ka}, 6 \mathrm{ka}$, and PI are based on 100 years. b2k is here defined by years before the year $2000 \mathrm{CE}$.

\begin{tabular}{lcll}
\hline $\begin{array}{l}\text { Time slice } \\
\text { acronym }\end{array}$ & $\begin{array}{l}\text { Model } \\
\text { years }\end{array}$ & $\begin{array}{l}\text { Start year, } \\
\text { relative } \\
\text { calendar }\end{array}$ & $\begin{array}{l}\text { Period, } \\
\text { Gregorian } \\
\text { calendar }\end{array}$ \\
\hline $8 \mathrm{ka}$ & $1001-1100$ & $7999 \mathrm{~b} 2 \mathrm{k}$ & $6000-5901 \mathrm{BCE}$ \\
$7 \mathrm{ka} *$ & $1961-1990$ & $7039 \mathrm{~b} 2 \mathrm{k}$ & $5040-5011 \mathrm{BCE}$ \\
$6 \mathrm{ka}$ & $3001-3100$ & $5999 \mathrm{~b} 2 \mathrm{k}$ & $4000-3901 \mathrm{BCE}$ \\
$5 \mathrm{ka}^{*}$ & $4001-4100$ & $5000 \mathrm{~b} 2 \mathrm{k}$ & $3001-2971 \mathrm{BCE}$ \\
$3 \mathrm{ka}^{*}$ & $6001-6030$ & $2999 \mathrm{~b} 2 \mathrm{k}$ & $1000-971 \mathrm{BCE}$ \\
$0.3 \mathrm{ka}^{*}$ & $8701-8730$ & $299 \mathrm{~b} 2 \mathrm{k}$ & $1700-1729 \mathrm{CE}$ \\
$\mathrm{PI}$ & $8751-8850$ & $249 \mathrm{~b} 2 \mathrm{k}$ & $1750-1849 \mathrm{CE}$ \\
\hline
\end{tabular}

The slowly evolving orbital parameters (a) and smoothed greenhouse gases (b) are updated for every decade. The other forcing mechanisms, sulfate aerosols (c), spectral solar irradiance (d), and land-use data (e) are read annually and calculated daily by linear interpolation. A detailed description on the transient simulation and the forcing mechanisms is given in Bader et al. (2019) and Brovkin et al. (2019).

The dependence of the AHP end on the initial vegetation conditions was not tested. However, based on previous simulations in similar model versions, we do not expect multiple vegetation conditions for the Sahara of the early MidHolocene, so the results of this study are assumed to be independent of the initial conditions. Nevertheless, it should be noted that initial conditions and the model setup may have an impact on transient simulations and their interpretation (cf. Braconnot et al., 2019).

For some analyses, daily output was needed. For this purpose, a few 30-year-long time-slice experiments were rerun that represent snapshots of decreasing orbital precession and north African humidity. For these time slices, periods with low volcanic activity were selected. Here we chose ad hoc periods around 7, 5, 3, and $0.3 \mathrm{ka}$ (Table 1). As the Earth's orbital parameters change over time, the length of the seasons varies for the different time slices. To avoid artefacts of the fixed calendar (i.e. the modern calendar) used in the climate models, daily output has been reassigned to months defined by a fixed angle on the Earth's orbit following Bartlein and Shafer (2019).

\subsection{Defining the end of the African humid period in the model}

In order to assess the end of the African humid period in the transient simulation, we analyse changes in the bare soil frac- 


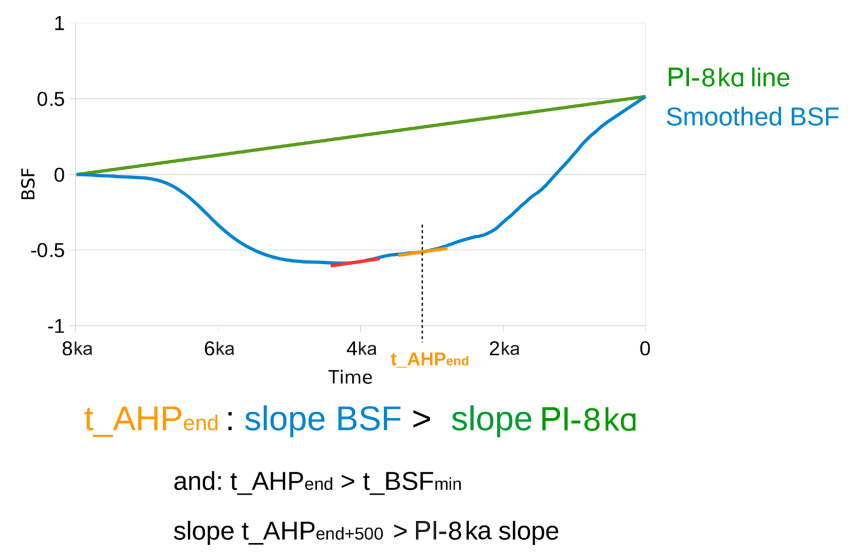

Figure 1. Sketch of the definition of the AHP end in the model. We calculate the AHP end based on the strongly smoothed (loess filter, span $=70$ ) bare soil fraction (BSF) change. The time step $T_{\text {end }}$ at which the slope between two consecutive time steps exceeds the slope of a straight line between the PI and the 8 ka bare soil fraction is regarded as the end of the AHP. Additionally, the minimum of the bare soil fraction has to precede $T_{\text {end }}$ and after 500 years, the slope has still to be larger than the slope of the straight line.

tion (BSF) assuming that the BSF is an appropriate indicator for the moisture availability in this region (see Sect. 2.1). For this purpose, we strongly smoothed the time series for each grid cell by performing a local regression with a smoothing span of $70 \%$ using the LOESS routine in $\mathrm{R}$ ( $\mathrm{R}$ core team, 2014). To define the onset of drying, we determined the first inflection point $\left(T_{\text {end }}\right)$ in the smoothed BSF record where the slope of two consecutive years exceeded the slope of a straight line between the BSF at $8 \mathrm{ka}$ and PI (Fig. 1). To ensure that this drying reflected the end of the AHP, we additionally imposed the constraints that (i) $T_{\text {end }}$ occurs after the minimum in BSF (peak wet conditions) and (ii) that the slope of the BSF curve remains larger than the straight line between $8 \mathrm{ka}$ and PI. Although this approach is relatively simplistic, given the relatively coarse temporal resolution of the proxy reconstructions, this approach is likely sufficient for comparison with the large-scale patterns in the timing of drying evident in the proxy data. For grid cells showing an increasing BSF over the Holocene, the AHP end is assigned to PI (i.e. the end of the simulation).

\subsection{Proxy data synthesis}

For comparison with the modelling results, we revised and expanded the proxy data synthesis of hydro-climatic changes at the end of the AHP previously published in Shanahan et al. (2015). Our new synthesis includes 138 records from sites across north Africa (see the Supplement). We revised the data compilation to include additional records published after or not identified in the earlier synthesis. A few records that are affected by deflation or have a temporal resolution that is too low, and therefore do not represent the decrease in precipi- tation accurately enough, were excluded because the end of the AHP could not properly be identified in these records. For each record in the synthesis, we identified the first major decline in precipitation or hydro-climate from the proxy data time series in order to be as consistent as possible with the model output. An exception was made when the initial onset of drying was followed by a substantial return to wetter conditions, indicating that the initial drying was not associated with the end of the AHP. The identification of the AHP end was performed visually because the noisiness of the data made it impossible to use other techniques such as change point analysis on most records.

We excluded marine sites in the model-data evaluation because of the uncertainties associated with comparing the model-derived moisture estimates against the marine proxy records, which receive terrestrial contributions (fluvial or aeolian) from potentially distant source regions. We are aware of the fact that the undefined and varying source area also complicates the comparison of the model results and the terrestrial records. While the model mainly shows the local conditions, the reconstructions may be influenced from regional or extra-regional changes (e.g. extra-regional pollen load). However, we assume that the extra-regional influence is less pronounced in the terrestrial records.

Another caveat in the records is the partly very poor dating and the coarse temporal resolution probably leading to additional uncertainty in the assessment of the AHP end time. To better compare the reconstructions with the model results, we therefore round up the AHP ends in the records and in the model to 500-year intervals.

An alternative approach that partly overcomes the abovementioned caveat is to compare the simulated and reconstructed patterns of drying, only. To do so, we estimated the relative timing of the end of the AHP for each grid cell containing a proxy site. By simply summing up the different sites and grid cells, we determined whether the AHP end was earlier, later, or the same as in the other sites and grid cells.

\section{Evaluation of the simulation}

\subsection{Precipitation patterns}

One of the main issues in current model experiments simulating the mid-Holocene is the strong underestimation of precipitation and of the northward extend of the rain belt over north Africa compared with reconstructions (e.g. Braconnot et al., 2012). Our simulations improve somewhat upon this discrepancy, but they still show some important differences. The simulated mid-Holocene annual mean deviation from the present-day precipitation within MPI-ESM is substantially larger than the one inferred previously from modelling studies (i.e. PIMP3) and more consistent with quantitative precipitation estimates from pollen data (Bartlein et al., 2011) (Fig. 2). At the same time, however, our simulations also show higher regional rainfall maxima and a 

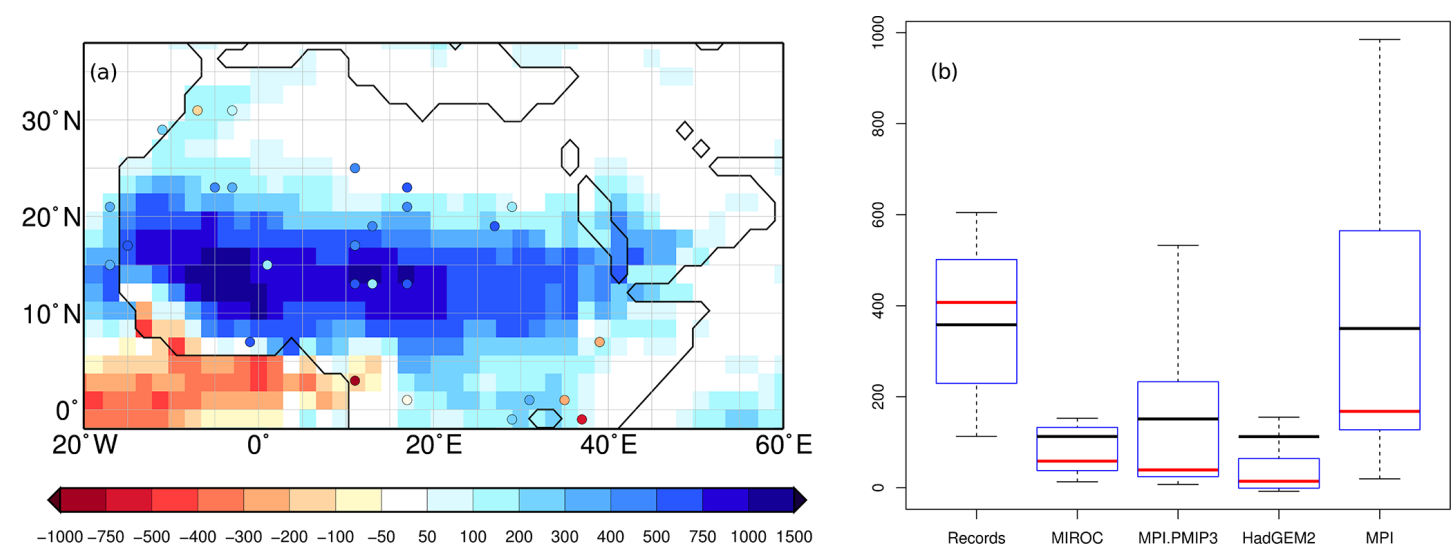

Figure 2. (a) Simulated (shaded) and reconstructed (dots; Bartlein et al., 2011) difference in annual mean precipitation (mm yr ${ }^{-1}$ ) between $6 \mathrm{ka}$ and and (b) boxplot of the annual mean precipitation difference $\left(\mathrm{mm} \mathrm{yr}^{-1}\right)$ between $6 \mathrm{ka}$ and PI based on all available records north of $10^{\circ} \mathrm{N}$ (Bartlein et al., 2011; cf. Braconnot et al., 2012) and the grid cells in the different models, in which the sites of these records are located. Considered are the PMIP3 models including dynamic vegetation (MIROC, MPI.PMIP, HadGEM2) and the model used in this study (MPI). Also shown are the mean (black line) and the median (red line).

larger range of spatial variability in precipitation than seen in the proxy data. Furthermore, the median value for midHolocene precipitation changes in our simulations is significantly lower than suggested by the proxy reconstructions (Fig. 2b). Although some of these discrepancies may be associated with the limited spatial coverage in the proxy data, there are some important features in the proxy data that the model fails to capture. Most significant amongst these is the fact that the northward extent of the monsoon rain belt is still underestimated in our simulations (Fig. 2a). Our simulations also show particularly large precipitation changes in the Sahel $\left(>1000 \mathrm{~mm} \mathrm{yr}^{-1}\right)$ that exceed existing pollenbased estimates (Bartlein et al., 2011) but are consistent with recent estimates from the hydrogen isotope composition of leaf wax biomarkers in marine sediments from the same latitudes (cf. Tierney et al., 2017). Regardless, it appears that in our simulations the monsoon rain belt is trapped between 10 and $20^{\circ} \mathrm{N}$, unable to expand northward into the Sahara, in disagreement with the proxy evidence for wetter conditions throughout the Sahara during the mid-Holocene. Only the northwestern-most Sahara (west of $0^{\circ}$ ) received much more rainfall during the mid-Holocene, with changes of up to $200 \mathrm{~mm} \mathrm{yr}^{-1}$ in that region. As a consequence of the limited northward shift of the rain belt in the MPI simulations, precipitation is presumably underestimated over most of the Sahara and overestimated in the Sahel compared with reconstructions.

\subsection{Vegetation distribution}

Figure $3 \mathrm{a}$ and $\mathrm{b}$ show the reconstructed and simulated PI and 6 ka vegetation distributions in the form of mega-biomes that have been calculated on the basis of the simulated plant functional type fractions and respective bioclimate, following the method of Dallmeyer et al. (2019). The simulated PI extent of the various mega-biomes agrees well with modern reconstructions (BIOME6000; Harrison, 2017) except for equatorial east Africa where the model overestimates the desert area. As expected, vegetation cover is strongly increased over most of north Africa at mid-Holocene. The steppe biome is shifted northward by up to $10^{\circ}$, leading to a large expansion of the savanna and tropical forest belts. Grasslands are more widespread along the northwestern Saharan coast, reaching far onto the continent. In the western Sahara, the simulated change in the grassland biome pattern strongly matches the BIOME6000 reconstructions but the extent of the steppe is underestimated with respect to the northern and southern boundary in the central Sahara. According to reconstructions, large parts of the Sahara were vegetated (Jolly et al., 1998), but the model indicates that the northward shift in the desertsteppe border only reached $22^{\circ} \mathrm{N}$. Interestingly, almost every grid cell in the model was at least to $10 \%$ covered by vegetation at some point during the African humid period (Fig. 3c). Only a small region in northeast Africa was desert during the entire 7850 years of simulation. This Holocene minimum in desert extent agrees well with the extent of the vegetation derived for $6 \mathrm{ka}$ in reconstructions, indicating that at least for some time during the Holocene the model shows a similarly strong vegetation change as the reconstructions. In total, the model shows strong vegetation changes during the last 8000 years. The vegetation cover in north Africa has almost halved from $8 \mathrm{ka}$ to PI. While the mean vegetation varies smoothly over the course of the Holocene, individual grid cells suggest heterogeneous vegetation dynamics with different starting times of the vegetation decline (Fig. 3c). A map showing the transient vegetation change for all north African grid cells is provided in Appendix B (Fig. B1) and in a higher resolution in the Supplement. 

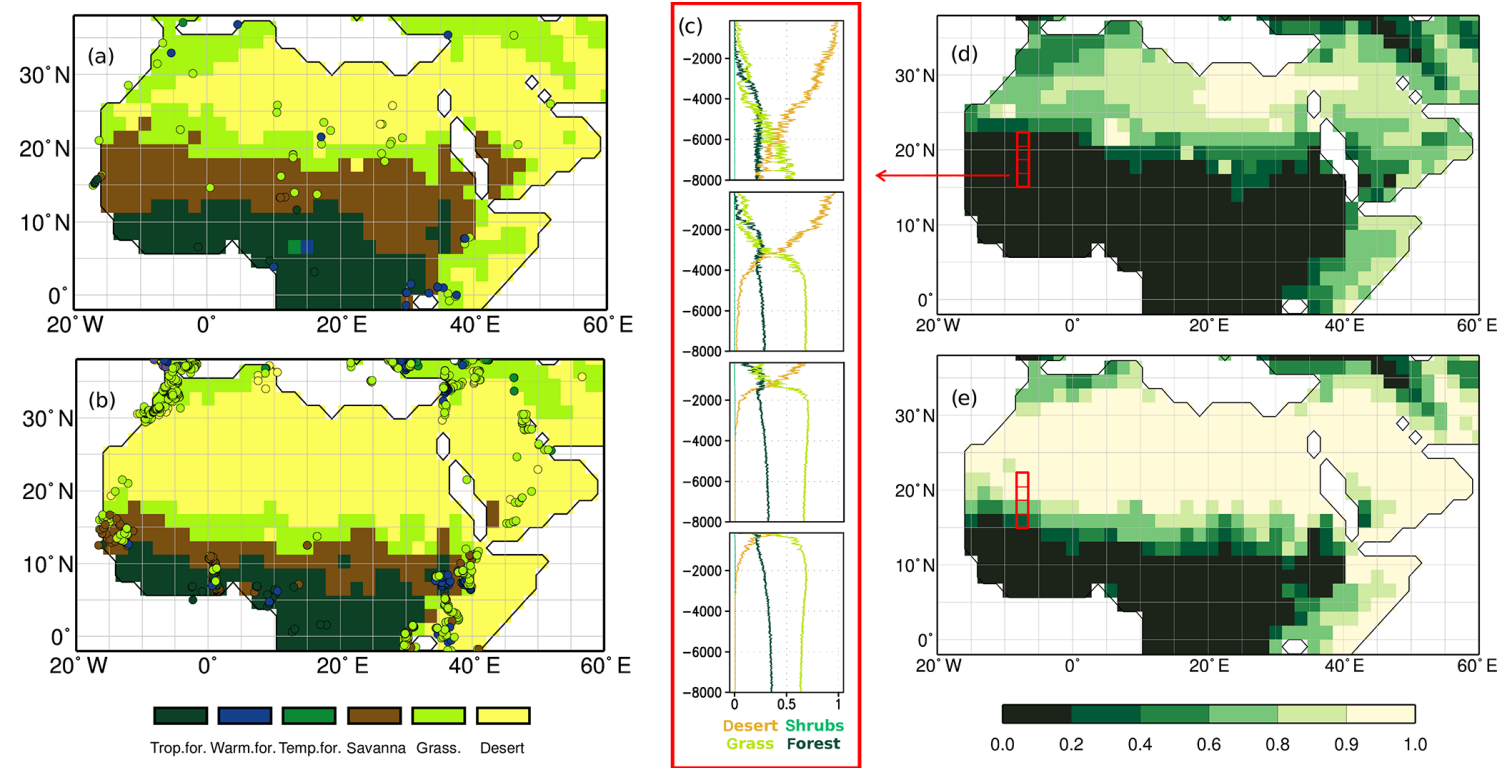

Figure 3. (a) Mid-Holocene (6 ka) and (b) preindustrial (PI) biome distributions based on the simulated plant functional types, following Dallmeyer et al. (2019). The reconstructed biomes (BIOME6000 project; Harrison, 2017) are displayed as dots. (c) Simulated change in main PFT cover fraction (i.e. desert, grass, shrubs, and forest fraction) from $8 \mathrm{ka} \mathrm{(-8000)} \mathrm{until} \mathrm{preindustrial} \mathrm{for} \mathrm{four} \mathrm{grid} \mathrm{cells} \mathrm{in} \mathrm{the} \mathrm{western}$ Sahel (red boxes in $\mathbf{d}$ and e); (d) simulated minimum desert fraction during the Holocene and (e) preindustrial desert fraction (PI). A figure showing the transient vegetation change in all north African grid cells is provided in Appendix B (Fig. B1) and in higher resolution in the Supplement.

\section{Results and discussion}

\subsection{Proxy-model comparison of the African humid period}

In agreement with the updated proxy data synthesis, the model indicates a time-transgressive end of the AHP (Fig. 4). The wet period ends earlier in the north than in the south and earlier in the east than in the west. In addition, the model shows significant differences in the timing of drying between the eastern and western Sahara. However, these differences are not captured in the reconstructions because of the low spatial density of records in this region. As expected, due to the low temporal resolution of the proxy data and model biases, the kappa metric (Cohen, 1960) reveals only a poor match between the simulated AHP end periods and the reconstructions $(\kappa=0.03)$. However, we note that this method has a tendency to underestimate the agreement in maps which are offset against each other (Foody, 2002; Tang et al., 2009).

There is much better agreement between the model and proxy data comparing the pattern of the relative timing of the AHP termination $(64 \%, \kappa=0.42$, Fig. 4). This suggests that while the absolute timing of drying in the proxy and model data do not match well, the spatial patterns in the differences in the onset, with some areas drying earlier and others drying later, is reproduced by the simulation. With few exceptions, the mismatched sites are all located in eastern Africa (east of $30^{\circ} \mathrm{E}$ ) and along a $5^{\circ}$ latitude-tilted band at the modern Sahara-Sahel boundary, where the model indicates that the AHP ended later than suggested by the reconstructions. This region of disagreement coincides with the transition from the area where precipitation is rather overestimated (roughly south of $18^{\circ} \mathrm{N}$ ) to where it is underestimated (Sahara) at $6 \mathrm{ka}$. We infer that the discrepancies thus reflect regional biases in the model simulations of the northward extent of the monsoon rain belt; the rain belt remained in this region too long before retreating to its current position in the late Holocene.

In eastern Africa, the model suggests an earlier end of the humid period for most sites. At least part of this mismatch may be caused by the complex orography in eastern Africa, which is only poorly represented in the coarse resolution of the model. Therefore essential regional circulation systems (such as the Turkana jet) are missing or at least poorly represented in the model. Furthermore, the coarse resolution orography could impede the simulation of the Indian monsoon development. On the other hand, some terrestrial reconstruction may rather portray the local changes in climate instead of the regional trend.

\subsection{Rainfall regimes and the time-transgressive termination of the African humid period}

Vegetation changes in northern Africa are highly coupled with changes in available moisture. To understand the causes of the time-transgressive end of the AHP, a detailed analysis 

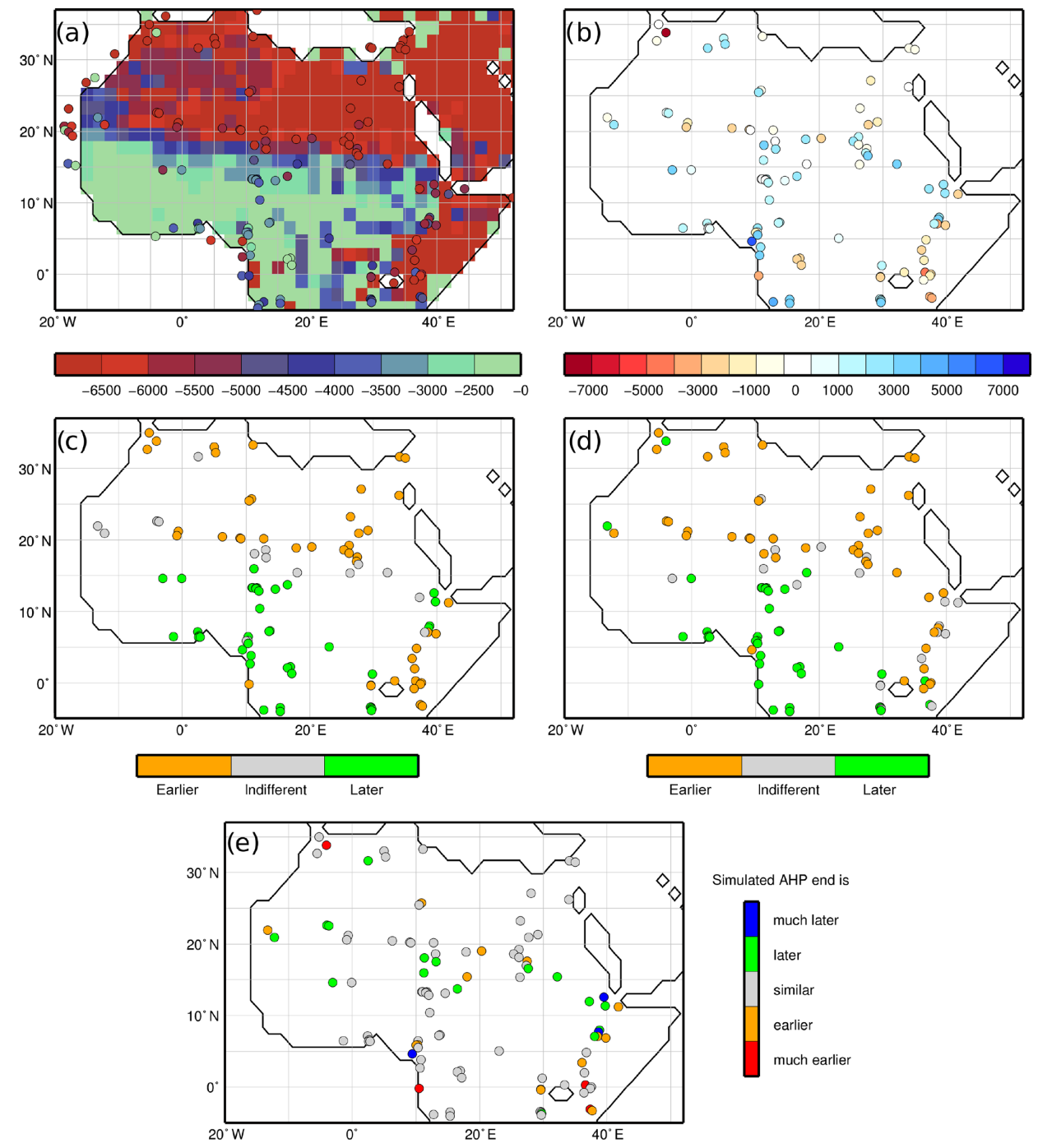

Figure 4. (a) Simulated end of the AHP at each individual grid cell (shaded) and reconstructed end by Shanahan et al. (2015). (b) Absolute difference (years) between the AHP end in the model and in the reconstructions. (c-e) Comparison of the relative timing of the AHP end in the model and the reconstructions. For this, the simulated end times have been assigned to 500-year intervals being comparable to the temporal resolution of the records. (c) For each grid cell in the model in which a record site is located, it was calculated if the simulated AHP end was earlier than (orange), later than (green), or similar (grey) as to that of most other grid cells in which sites are located. (d) Same as (c) but for the records (e) difference of the relative timing (model minus records), e.g. "much earlier" (red) indicates sites at which the relative time based on the model results was classified at a much earlier point in time than based on the records. Please notice that for the comparison only terrestrial sites have been used.

of the precipitation changes is thus indispensable. Figure 5 shows the onset pentad (i.e. intervals of $5 \mathrm{~d}$ ) and length of the rainy season for the $7 \mathrm{ka}$ time-slice simulation (cf. Table 1), calculated on the basis of the definition by Wang and LinHo (2002). Similar as for the AHP end, both patterns indicate a north-south and east-west gradient. The rainy season begins earlier and lasts longer in the south than in the north and begins earlier and lasts longer in the west than in the east, which is to a large part related to the seasonal march of the west African summer monsoon penetrating inland from the Gulf of Guinea. Only on the Ethiopian Plateau, the rainy sea- son also starts very early in the year. In the monsoon-affected region outside the area with perennial rainfall (i.e. the continental area between $7.46-37.21^{\circ} \mathrm{N}$ and $19.69^{\circ} \mathrm{W}-53.44^{\circ} \mathrm{E}$ ), the end of the AHP is negatively correlated with the onset of the rainy season at $7 \mathrm{ka}(r=-0.56)$ and strongly positively correlated with the rainy season length $(r=0.61)$. The length of the rainy season thus already explains more than one-third of the spatial variability of the AHP end. This underlines that the timing of the AHP end is strongly connected to the rainfall changes or, more precisely, with changes in the number, 
the extent, and the duration of the strong rain events bringing most of the precipitation.

We are aware of the fact that the $7 \mathrm{ka}$ time slice is only a snapshot, but in principle the pattern looks very similar in other time slices, although the region receiving precipitation is of course shrinking throughout the Holocene. Additionally, it is reasonable to assume that the regions experiencing the latest onset and shortest rainy season at $7 \mathrm{ka}$ are also the regions in which the rainy systems decrease and disappear first in the course of the Holocene.

Although much of north Africa is strongly influenced by the west African summer monsoon, the impact of the monsoon circulation on seasonal rainfall can differ significantly, depending on location. For example, the monsoon rainy season starts earlier near the southern coast, ends later, and is associated with drier conditions in July and August, when monsoon rainfall is at a maximum over the Sahel. Furthermore, northwestern Africa ( $>20^{\circ} \mathrm{N},<20^{\circ} \mathrm{E}$ ) and occasionally also northeastern Africa are also affected by extratropical troughs developing in the subtropical jet, which can advect significant amounts of tropical moisture into the Sahara in the form of concentrated plumes of water vapour (Knippertz, 2003, 2007; Knippertz et al., 2003). Figure 6 shows the typical daily mean precipitation and upper-tropospheric wind pattern for a strong rain event in the Sahara, based here on a day in October taken from the $7 \mathrm{ka}$ time-slice simulation. The Rossby wave train is well displayed and embedded in the strong subtropical jet forming an upper-lever trough with a SW-to-NE-orientated axis that reaches far into the low latitudes. On the eastern flank of the trough, a broad cloud band develops (so called tropical plume, not shown) extending from the tropics to the Mediterranean. The tropical plume coincides with abundant rainfall that is further favoured by the divergence in the outflow of the jet streak and the related positive vorticity advection (not shown). Lower tropospheric air can thus be transported rapidly into the subtropical upper troposphere (e.g. Fröhlich, 2013, and references therein). The rainfall for this simulated event exceeds $25 \mathrm{~mm} \mathrm{~d}^{-1}$ in some parts of the Sahara. In general, rain events associated with tropical plumes usually provide more than half of the mean annual precipitation at present, sometimes within only a few days, leading to widespread flooding and destruction (Knippertz and Martin, 2005). Tropical plumes are therefore a factor that should not be neglected in rainfall analysis for north Africa.

The differences in the timing and the sources of precipitation result in distinct regional climatologies. Here, to better distinguish these regional differences in rainfall seasonality, we performed a $c$-means clustering (Meyer et al., 2014) based on preindustrial monthly-to-annual rainfall and identified the following distinct rainfall regimes (Fig. 7):

a. The equatorial zone (yellow) includes year-round precipitation with a double rainfall peak (spring and au- tumn) related to the seasonal advance and the retreat of the monsoon rain belt over the region.

b. The monsoon domain (orange) includes a typical monsoonal seasonal cycle with a single rainfall maximum in summer (August).

c. The westernmost Sahara (red) includes contributions from both the summer monsoon and extratropical troughs, which produce an extended rainfall peak in August and September.

d. The northwestern Sahara (green) includes autumn and winter precipitation, strongly effected by ETIs with peak precipitation in October and November.

e. The eastern Sahara (blue) includes limited wintertime precipitation, peaking in December and January.

We hypothesize that the change in the orbital forcing throughout the Holocene affects these rainfall "regimes" differently, leading to regional differences in the timing of the end of the AHP. The Holocene orbital forcing induces mainly a seasonal signal as the changes in insolation mostly compensate each other in the annual mean. Due to the different seasonal rainfall cycles, modifications in the dynamics of the key players (i.e. summer monsoon and ETI) should result in different responses to the orbital forcing in the respective regions.

\subsection{Changes in the dynamics of the major rainfall-bearing atmospheric circulations}

\subsubsection{The west African monsoon system}

At $7 \mathrm{ka}$, the summer-monsoon-related inflow from the Atlantic ocean appears as a broad, zonally orientated wind belt reaching up to $18^{\circ} \mathrm{N}$ that turns north towards the Red Sea at longitudes east of $20^{\circ} \mathrm{E}$ (Fig. 8a). The moisture flux onto the continent and into the Sahara is much stronger at $7 \mathrm{ka}$ than during the $0.3 \mathrm{ka}$ time slice. Convergence occurs over a significant portion of north Africa (ca. $0-25^{\circ} \mathrm{N}$ ), reflecting the expanded latitudinal range of the monsoon rain belt during the mid-Holocene. The exception to this is the eastern Sahara where precipitation remains low because of low-level moisture divergence at this time. The boundary between moisture convergence and divergence is inclined by approx. $20^{\circ} \mathrm{NW}-$ $\mathrm{SE}$, representing the inclined rainband. As a result, gradients at the AHP end are already manifested in a "tilted" monsoon system.

The general pattern of moisture convergence changes only slightly during the Holocene, instead showing a weakening trend that is consistent with the gradual decline in insolation forcing. The reduction in monsoon strength can be described by a simple monsoon index, which we define here as the relative change in the product of moisture and zonal wind speed at $850 \mathrm{hPa}(=q \cdot u)$, averaged over the western 

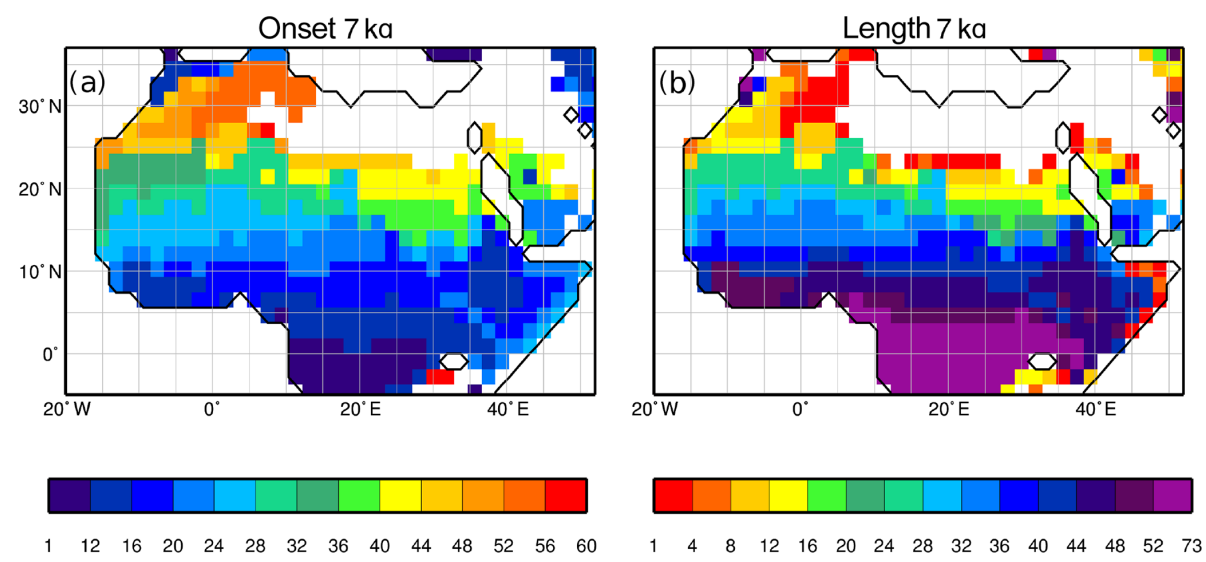

Figure 5. Simulated (a) monsoon onset pentad (i.e. $5 \mathrm{~d}$ interval) and (b) monsoon length (in pentads) for the $7 \mathrm{ka}$ time slice, on land only.

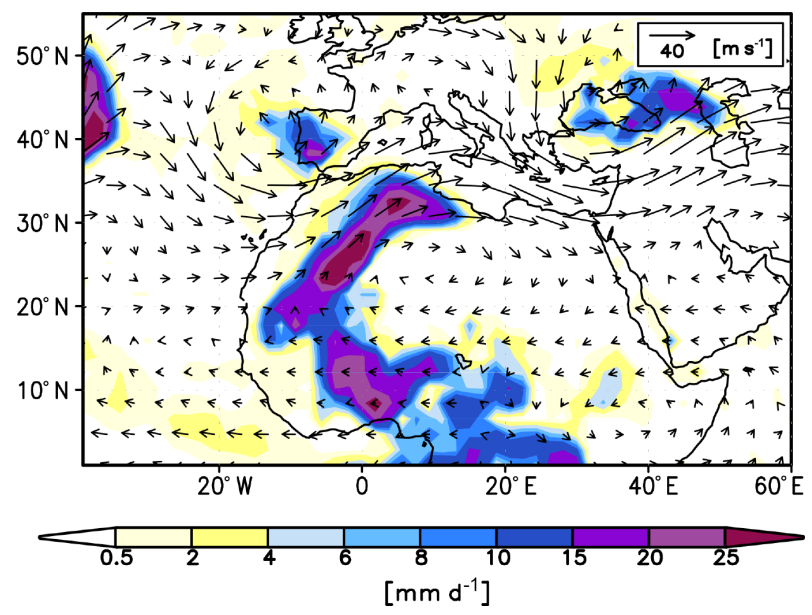

Figure 6. Example of a strong rain event of $1 \mathrm{~d}$ in October in the Sahara at $7 \mathrm{ka}$ : shown are the upper tropospheric wind $(300 \mathrm{hPa}$, vectors, $\mathrm{m} \mathrm{s}^{-1}$ ) and the daily mean precipitation $\left(\mathrm{mm} \mathrm{d}^{-1}\right)$.

Sahel $\left(10^{\circ} \mathrm{W}-0^{\circ} \mathrm{E}, 8-18^{\circ} \mathrm{N}\right)$. This zonal moisture inflow is more than 6-times stronger at $8 \mathrm{ka}$ than at PI (Fig. 8e) and decreases relatively linearly but more intensively from 8 to $3 \mathrm{ka}$ than from $3 \mathrm{ka}$ to PI. The decline in monsoon strength is accompanied by a reduction in the area affected by monsoon rains. The retreat of the main monsoon rainband is reflected by the bipolar convergence change in the monsoon domain, indicating a weakening of the low-level moisture flux convergence in the north and a strengthening of the flux in the south of the rain belt between two time slices (Fig. 8; see cyan line). This pattern is most prominent between 5 and $3 \mathrm{ka}$ (Fig. 8c).

Figure 9 displays the change in the extent of the monsoon rain belt, based on the $2 \mathrm{~mm} \mathrm{~d}^{-1}$ precipitation isohyet in the annual mean. These isolines are tilted with a similar angle as the time-isolines of the AHP end. The monsoon retreat occurs meridionally differently. In the most western part of the Sahel (west of $10^{\circ} \mathrm{W}$ ), the rain belt remains at its northern position for several thousand years, the strong retreat does

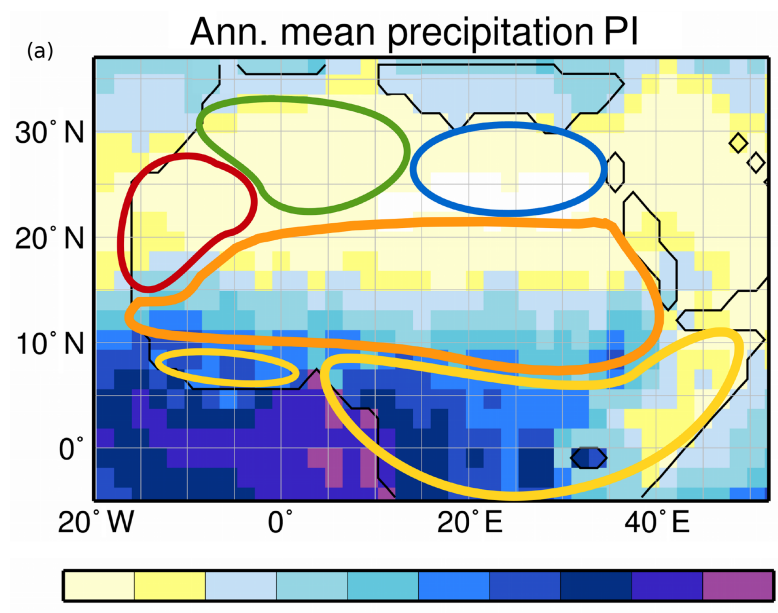

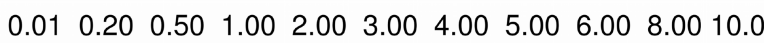

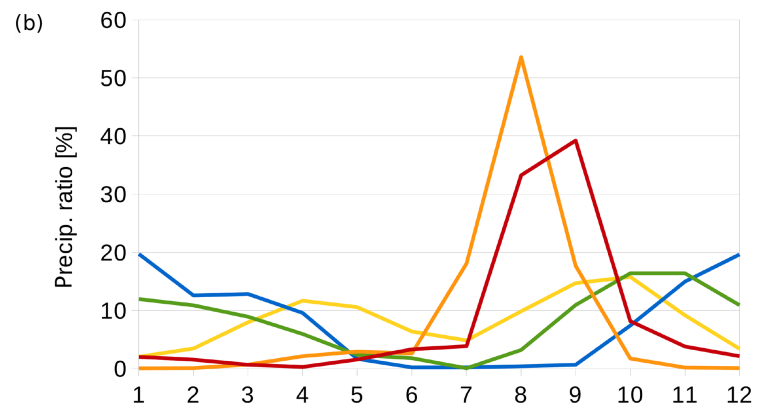

Figure 7. (a) Simulated preindustrial annual mean precipitation $\left(\mathrm{mm} \mathrm{d}^{-1}\right)$ and major rainfall regimes; (b) monthly preindustrial precipitation ratio $(\%)$ in the different regimes, i.e. the ratio of monthly mean precipitation to annual mean precipitation.

not start until $4 \mathrm{ka}$. Here it is noticeable, that the monsoon rain belt retreats more slowly in the early mid-Holocene than in the late Holocene. The spatial variability in the timing of the AHP end in the main monsoon domain strongly correlates $(r=0.84)$ with the position of the $2 \mathrm{~mm} \mathrm{~d}^{-1}$ isolines. 

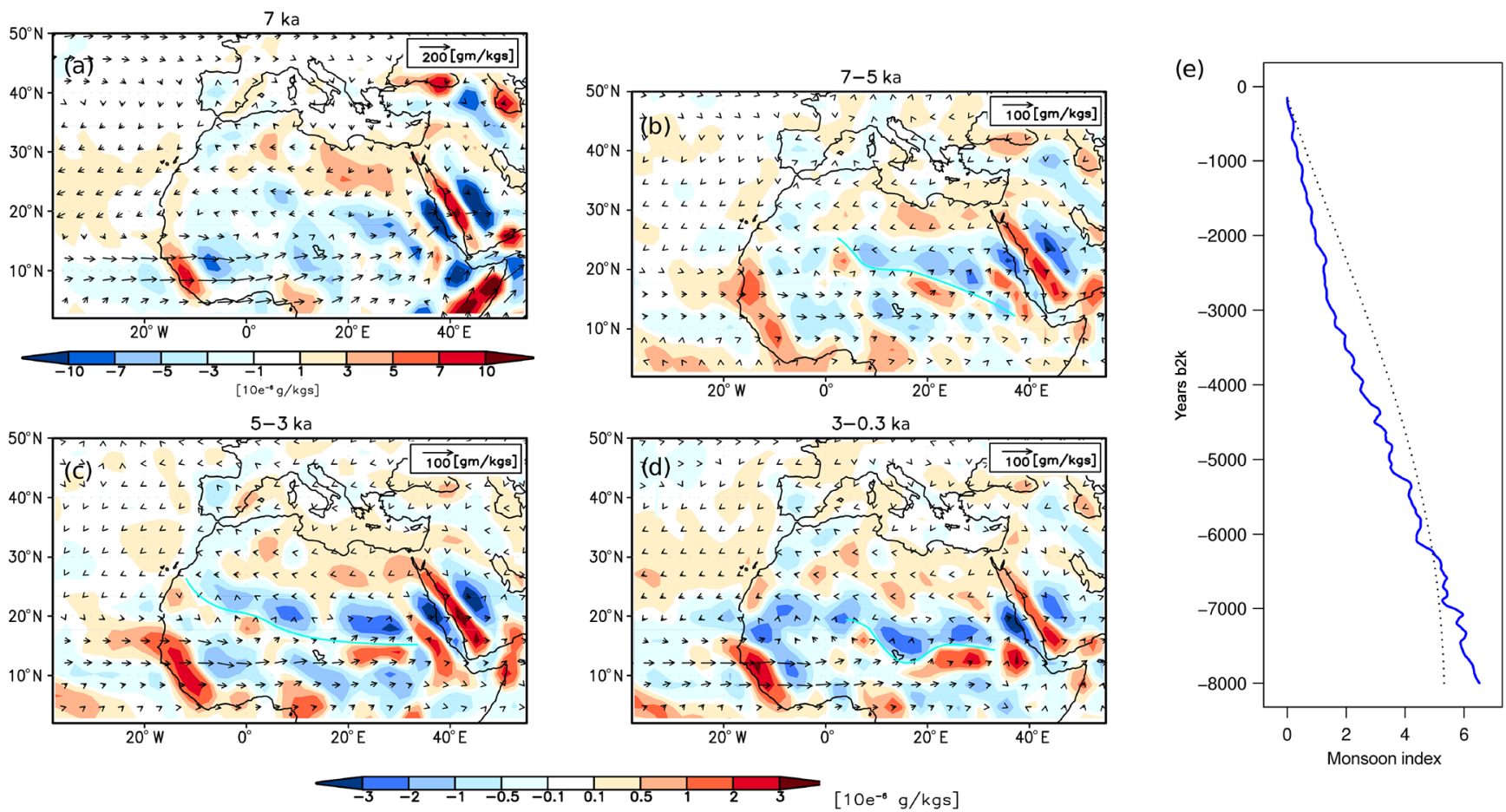

Figure 8. (a-d) Moisture flux (vector, in $\mathrm{g} \mathrm{kg}^{-1} \mathrm{~m} \mathrm{~s}^{-1}$ ) on the $850 \mathrm{hPa}$ level and its divergence (shaded, blue is convergence, red is divergence, in $10 \times 10^{-5} \mathrm{~g} \mathrm{~kg}^{-1} \mathrm{~s}$ ) for the months July-September (adjusted to fixed-angular calendar definition) for (a) $7 \mathrm{ka}$ and the differences (b) 7-5 ka, (c) 5-3 ka, and (d) 3-0.3 ka. In (b, c, d), the cyan line marks the area of transition between divergence and convergence related to the southward retreat of the monsoon rainband. (e) Smoothed change in monsoon strength, based on a simple index $(q \cdot u$, averaged over the region $10^{\circ} \mathrm{W}-0^{\circ} \mathrm{E}, 8-18^{\circ} \mathrm{N}$, blue), and the Rossignol-Strick Index (Rossignol-Strick, 1985) (black), both as relative change compared to PI $(t-\mathrm{PI} / \mathrm{PI})$.

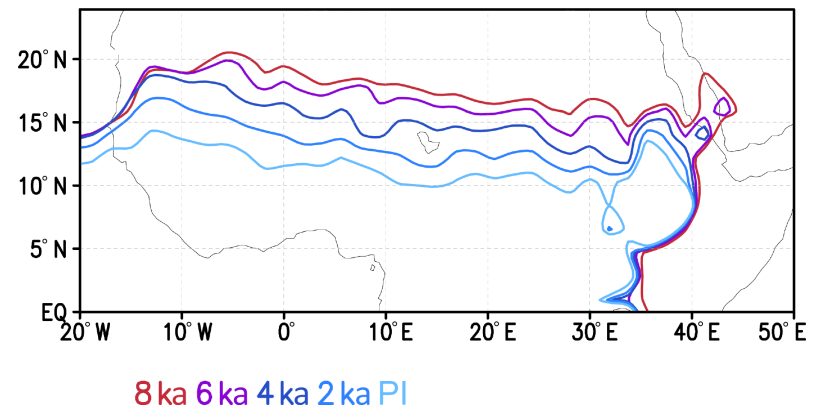

Figure 9. Change of the northernmost extent of the monsoon rainband, based on the simulated $2 \mathrm{~mm} \mathrm{~d}^{-1}$ annual mean precipitation isohyet.

Summarizing, the monsoon system gradually weakens during the Holocene, leading to a southward retreat of the monsoon rain belt, in line with the generally accepted orbital monsoon hypothesis (Kutzbach, 1981). The moisture flux reveals that the monsoon decline coincides with a strengthening of the low-level moisture flux convergence in the southern part of the monsoon domain and a weakening of the convergence at the northern boundary. This underlines why the AHP ends first in the northern part, where the moisture sink is weakened and remains in the southern part, where it is further enhanced. The AHP end in the main monsoon region can be explained fully by the retreat of the west African summer monsoon.

\subsubsection{The impact of changes in extratropical troughs}

To get an overview of the change in strong rain events associated with extratropical troughs during the Holocene, we analyse all rain events with daily rainfall exceeding $4 \mathrm{~mm} \mathrm{~d}^{-1}$ occurring in the Sahara within the 30 years of the individual time-slice simulations, following Skinner and Poulsen (2016).

Figure 10 shows the number of rain events $\left(>4 \mathrm{~mm} \mathrm{~d}^{-1}\right)$ in the Sahara at $7 \mathrm{ka}$ and the change in this number during the Holocene. At $7 \mathrm{ka}$, the western Sahara $\left(10^{\circ} \mathrm{W}-10^{\circ} \mathrm{E}\right.$ and 20 $35^{\circ} \mathrm{N}$ ) experiences more rain events compared to $5 \mathrm{ka}$, while in the region along the western Atlantic coast $\left(15-11^{\circ} \mathrm{W}, 20\right.$ $25^{\circ} \mathrm{N}$, further referred to as coastal area) rain events show the tendency to increase from 7 to $5 \mathrm{ka}$. This is the region indicating a pronounced delay in the timing of the AHP end. From 5 to $3 \mathrm{ka}$ and from 3 to $0.3 \mathrm{ka}$, rain events reduce strongly in both regions with increasing magnitude from the northeast to the southwest. 


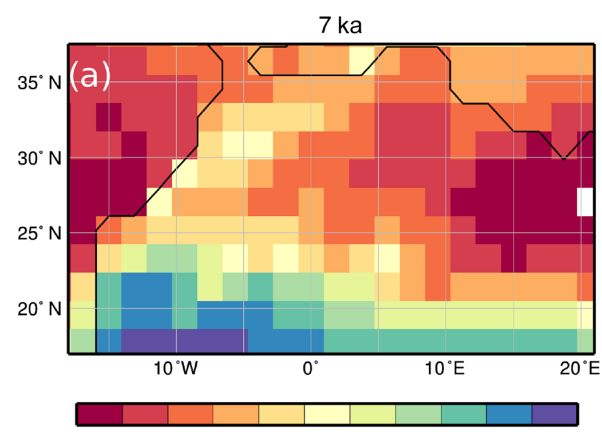

$\begin{array}{llllllllllll}0.1 & 1.0 & 2.0 & 4.0 & 6.0 & 8.0 & 10.0 & 15.0 & 20.0 & 25.0 & 30.0 & 35.0\end{array}$

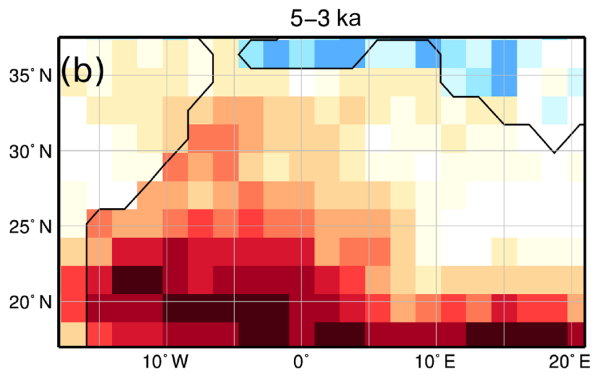

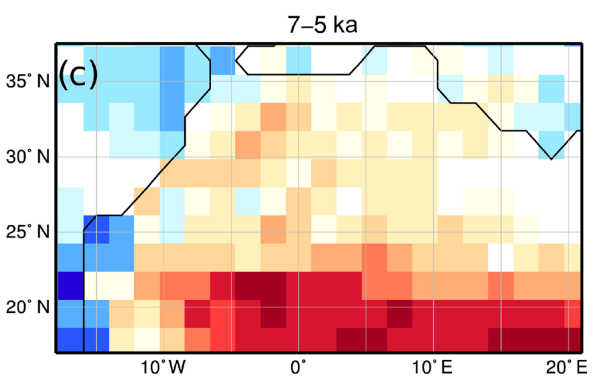

$3-0.3 \mathrm{ka}$

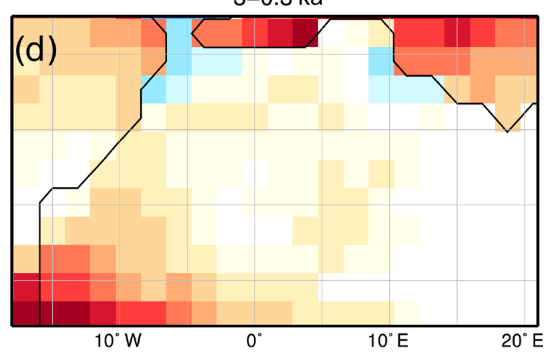

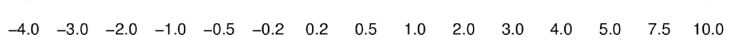

Figure 10. Number of rain events in September and October that exceed the $4 \mathrm{~mm} \mathrm{~d}^{-1}$ precipitation criteria for (a) the $7 \mathrm{ka}$ time slice, and for the differences in the number of rain events $\left(>4 \mathrm{~mm} \mathrm{~d}^{-1}\right)$ between time slices: (c) 7-5 ka, (b) 5-3 ka, and (d) 3-0.3 ka.

What are the atmospheric dynamics resulting in these regionally different trends between the coastal area and the central western Sahara? To answer this question, we need to look again at the special dynamics associated with rain events in northern Africa. Figure 11 shows the vertically integrated moisture flux anomalies during $7 \mathrm{ka}$ September and October for composites of all rain events occurring in the western Sahara and the coastal area, respectively, in comparison with the monthly mean flow. Rain events are not unusual in the coastal region during September. The composite mean differs only slightly from the monthly mean flow, showing just a little increased moisture flux convergence in Mauritania and at the Moroccan coast. This anomaly is mainly related to a slightly stronger, more northward turning monsoon flow and a more inclined AEJ at the coast compared to the monthly mean (for details, see Appendix A), resulting in an intensified moisture convergence there.

During October, these anomalies in the lower levels are much more pronounced. In addition, a slightly cooler or warmer upper troposphere above the Atlantic and eastern Sahara (centre ca. $27^{\circ} \mathrm{N}, 5^{\circ} \mathrm{W}$ ) triggers south winds along the northern coast.

Figure 11 underlines that strong rain events in the western Sahara not only coincide with a strong meridional moisture transport from low latitudes to the Mediterranean Sea but also with an abnormally strong monsoon-like inflow from the Atlantic, stretching deep onto the continent, independent of the month in which the events are occurring. The moisture flux diverges slightly more intensively over the eastern Sahara and converges distinctly over the western Sahara compared to the mean. This region of enhanced moisture convergence fits very well to the region in which the AHP end is delayed (i.e. later than $8 \mathrm{ka}$ ). Interestingly, the occurrence of rain events in the western Sahara seems to be unfavourable for precipitation along the western coast (and in the coastal area), as the moisture convergence is reduced there.

This pattern is at least partly related to changes in the AEJ (cf. Fig. A2 in Appendix A) that is substantially reduced in its outflow domain, diminishing the moisture transport to the coast. Besides the circulation anomalies coinciding with the strong equatorward extending trough in the upper troposphere that portray the classical pattern of an tropical plume situation (Fig. A1), heavy rain events in the western Sahara are associated with a strong cyclonic monsoon-like anomaly in the lower troposphere with strong south winds around $0^{\circ} \mathrm{E}$ (Fig. A3).

To summarize, the atmospheric conditions for heavy rain events in the coastal area are part of the normal late-monsoon circulation during September. This "mean" circulation is "maintained" during October, when abundant rain falls in this region. The subtropical jet meanders slightly and supports the formation of precipitation along the coast. In contrast, rain events in the western Sahara are related to a pronounced Rossby wave anomaly with cold air above the west- 

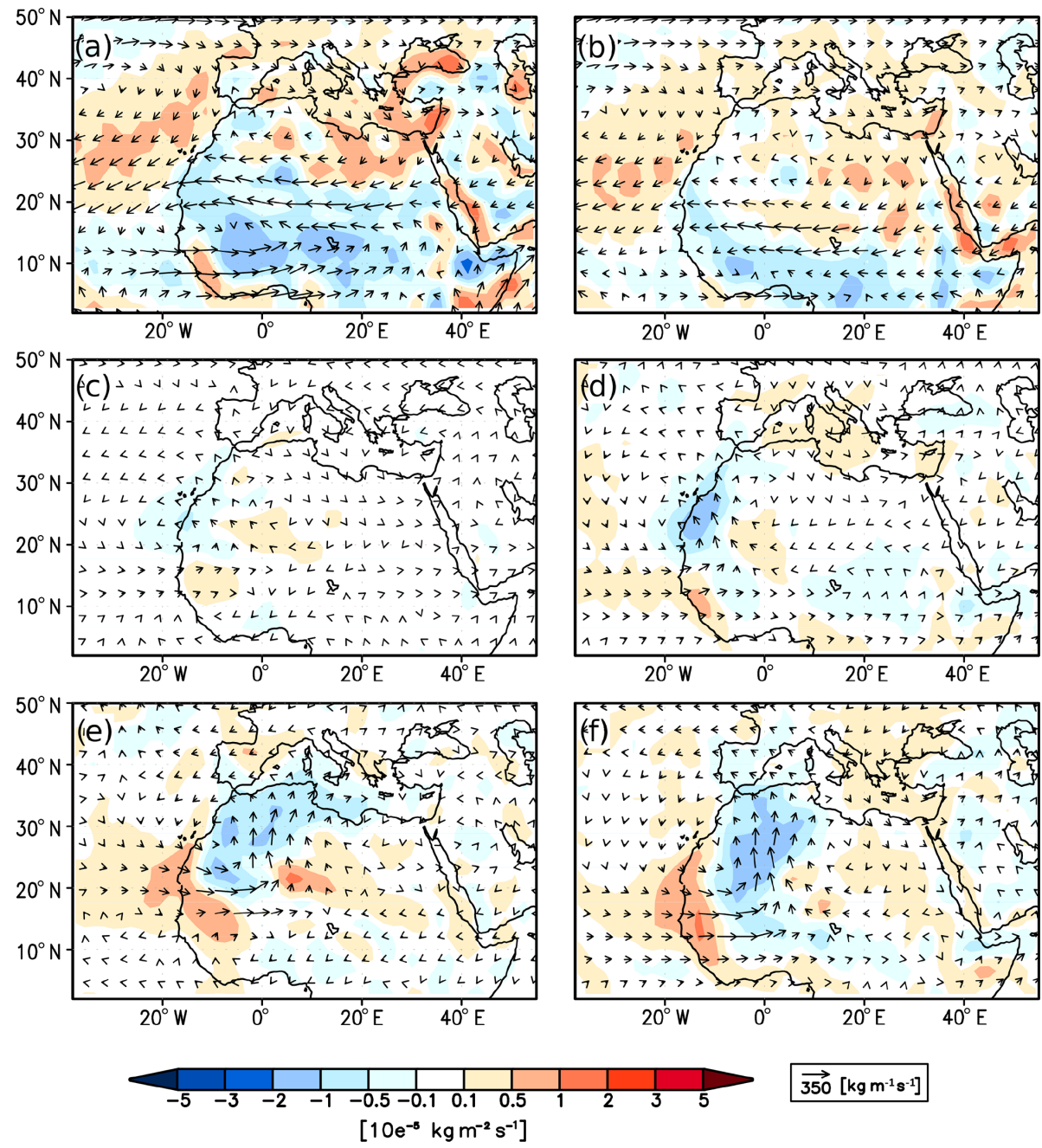

Figure 11. Monthly mean vertically integrated moisture flux (vectors, $\mathrm{kg} \mathrm{m}^{-1} \mathrm{~s}^{-1}$ ) and its convergence (shaded, convergence is blue, divergence is red, $10 \times 10^{-5} \mathrm{~kg} \mathrm{~m}^{-2} \mathrm{~s}^{-1}$ ) for (a) $7 \mathrm{ka}$ September and (b) $7 \mathrm{ka}$ October (both months have been adjusted to the fixed-angular calendar); (c, d) differences in vertically integrated moisture flux and its convergence between the composite of all rain events occurring in the coastal area $\left(15-11^{\circ} \mathrm{W}, 20-25^{\circ} \mathrm{N}\right)$ and the monthly mean flow for (c) $7 \mathrm{ka}$ September, (d) $7 \mathrm{ka}$ October; and (e, f) the differences between the composite of all rain events in the western Sahara $\left(20-35^{\circ} \mathrm{N}, 10^{\circ} \mathrm{W}-10^{\circ} \mathrm{E}\right)$ and the monthly mean flow for (e) $7 \mathrm{ka}$ September and (f) $7 \mathrm{ka}$ October. To convert the convergence in units of millimetre per day ( $\mathrm{mm} \mathrm{d}^{-1}$ ), please multiply by $86400 \mathrm{~s} \mathrm{~d}^{-1}$.

ern coast and the Atlantic, triggering a south wind anomaly in the central western Sahara throughout the entire troposphere. The position of this cold air anomaly determines whether rain falls along the coast (i.e. in the coastal area) or in the western Sahara. In the latter case, the anomaly is much more pronounced and centred on land, while in the case of heavy rain events at the coastal area the anomaly is centred about $10^{\circ}$ further westward, above the Atlantic.

During the course of the Holocene, the upper atmosphere experiences a cooling (decrease in geopotential) in September and October due to the decreasing insolation (Fig. 12). As the cooling is generally more pronounced in the northern latitudes than near the Equator, the upper level westerlies are continuously enhancing, and the subtropical jet penetrates more and more towards the Sahara. Therefore, the upper tro- pospheric conditions for the formation of rain events in the Sahara are generally improving during the Holocene.

During October, the upper level temperature above the northern Sahara and Mediterranean regions strongly decrease from 7 to $5 \mathrm{ka}$. This leads to a cyclonic anomaly centred at the Libyan coast and enhanced north winds above the western Sahara, resulting in mean atmospheric conditions that rather prevent the moisture from being transported out of the lower latitudes, favouring particularly the rain events at the coast. From 5 to $3 \mathrm{ka}$ upper tropospheric cooling in October is most pronounced above Spain and Morocco, resulting in a wind anomaly with anomalous south winds along $0^{\circ} \mathrm{E}$.

In the mid-troposphere, the warming of the continental interior (probably related to less precipitation and evaporative cooling) leads to a decrease in the meridional temperature 

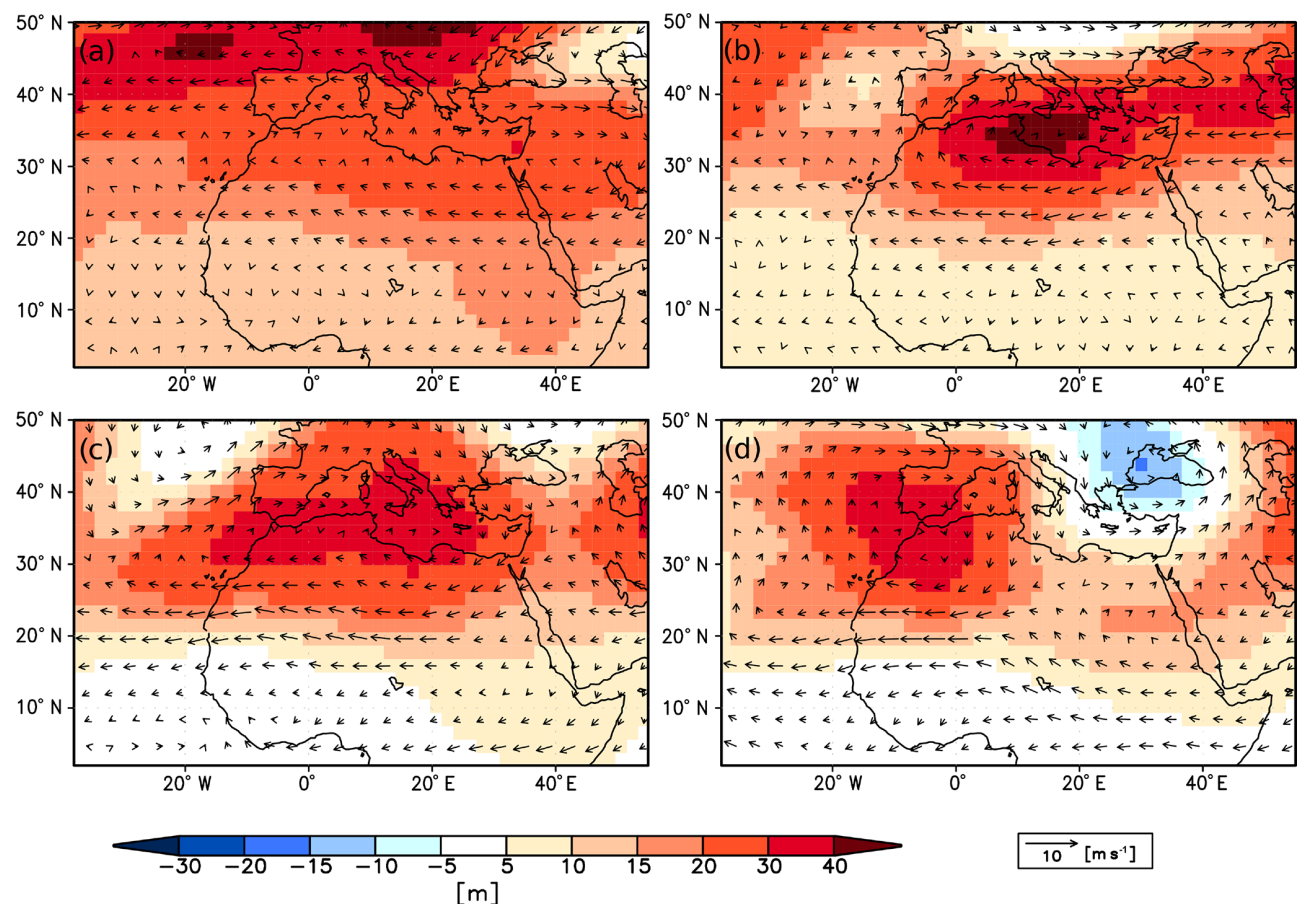

Figure 12. Change in $300 \mathrm{hPa}$ geopotential height (m, shaded) and $300 \mathrm{hPa}$ wind ( $\mathrm{m} \mathrm{s}^{-1}$, vector) from (a) 7 to $5 \mathrm{ka} \mathrm{September,} \mathrm{(b)} 7$ to $5 \mathrm{ka}$ October, (c) 5 to $3 \mathrm{ka}$ September, and (d) 5 to $3 \mathrm{ka}$ October, respectively. The months have been adjusted to the fixed-angular calendar.

gradient towards $5 \mathrm{ka}$ and a slight weakening and southward displacement of the African easterly jet (not shown). Directly at the coast, the wind is blowing from the south slightly more, favouring the coastal rain events rather than Saharan rain events at $5 \mathrm{ka}$. In the following millennia, mid-tropospheric temperatures in north Africa increase strongly so that the easterly flow is substantially reduced and the African easterly jet moves far to the south.

As discussed in Sect. 3.3.1, the west African monsoon is continuously weakening and retreating to the south during the Holocene. The changes in vertically integrated moisture flux displayed in Fig. 7 reflect the changes in the position of the monsoon rainband. They indicate that monsoonal moisture flux convergence during summer is enhanced in the coastal region at $5 \mathrm{ka}$ compared to $7 \mathrm{ka}$. West wind reaches still up to $15^{\circ} \mathrm{N}$ in October and the low-level wind field at the coast has a more pronounced southward component at $5 \mathrm{ka}$ compared to $7 \mathrm{ka}$ (Fig. 13), additionally favouring rain events in the coastal region. From 5 to $3 \mathrm{ka}$, the low-level temperature and with it the wind field change much more strongly. The monsoon is located far in the south and is no longer relevant for the north African atmospheric dynamics during October.

To summarize, the changes in the upper and midtropospheric dynamics are generally providing conditions that are getting more favourable for the formation of rain events in both the coastal region and in the western Sahara, towards the late Holocene. The upper level westerly winds penetrate deeper onto the north African continent, likely enhancing the probability of extratropical troughs that extend into lower latitudes. At 5 ka during October, the distinct temperature change in the Mediterranean region hampers the moisture transport to the western Sahara. The African easterly jet and the monsoon flow is continuously decreasing and moving southwards during the Holocene. However, the shifting of the perihelion towards autumn during mid-Holocene favours the intensification and maintenance of the (late) monsoon circulation. This is in line with the results of Skinner and Poulsen (2016). Due to the tilted structure of the monsoon system, tropical moisture can be transported deeper to the north along the western coast than in the eastern part, so the low-level moisture flux to the coast decreases only slightly from 7 to $5 \mathrm{ka}$. The African easterly flow and the monsoon are still present in the coastal area at $5 \mathrm{ka}$ and thus have the chance to interact with the upper tropospheric circulation. The interplay between a still strong and active monsoon circulation and the intensified upper-level westerlies tend to increase the coastal rain events in October during $5 \mathrm{ka}$ compared to $7 \mathrm{ka}$ (Fig. 10), contributing to the delay in the AHP end. In the following millennia, the monsoon dynamics and the extratropical troughs are spatially developing into distinct phenomena, i.e. the extratropical and tropical circulations are "decoupled". Their interaction is weaker and therefore less common after $5 \mathrm{ka}$. The number of rain events in both regions is reducing substantially during the late Holocene. 

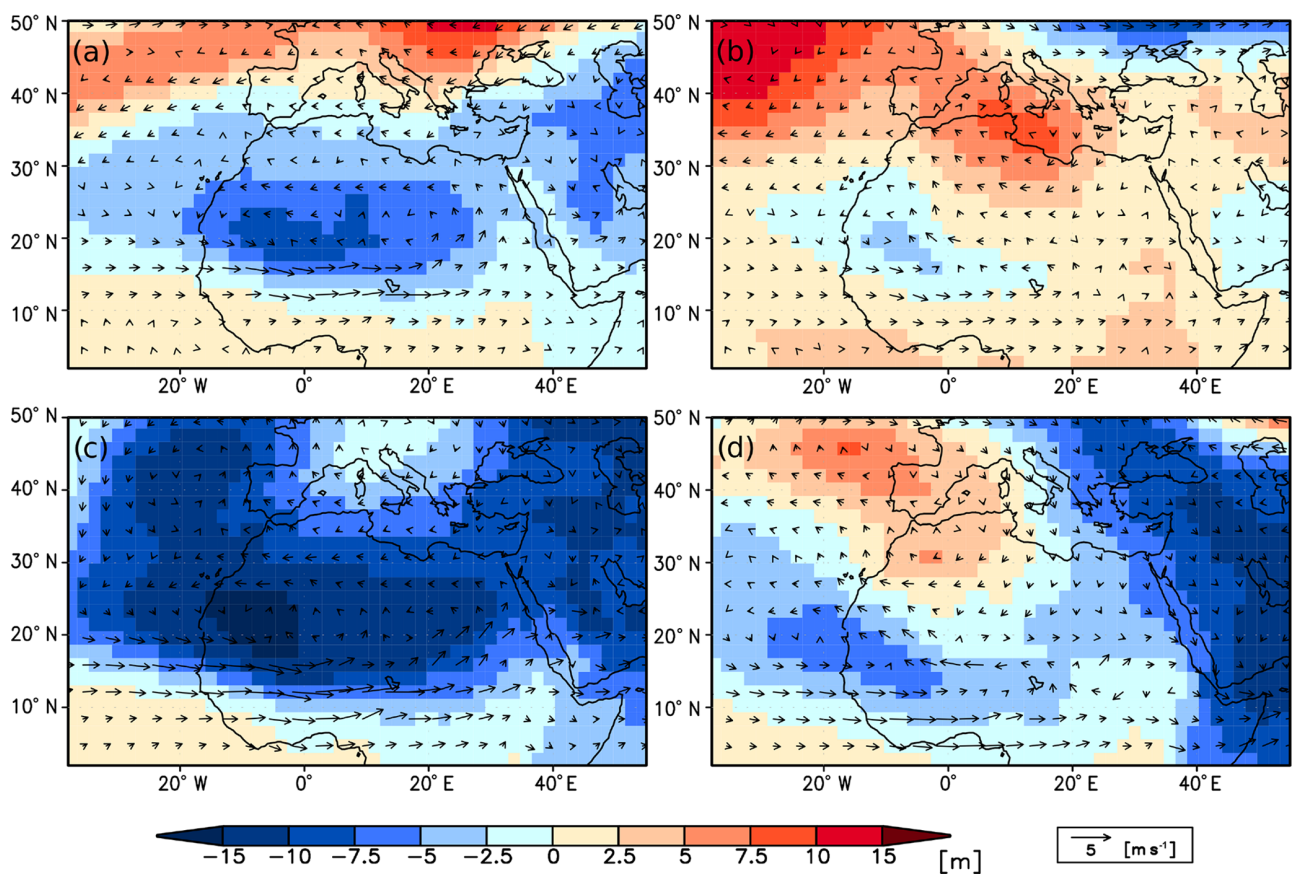

Figure 13. Change in $850 \mathrm{hPa}$ geopotential height (m, shaded) and $850 \mathrm{hPa}$ wind ( $\mathrm{m} \mathrm{s}^{-1}$, vector) from (a) 7 to $5 \mathrm{ka}$ September, (b) 7 to $5 \mathrm{ka}$ October, (c) 5 to $3 \mathrm{ka}$ September, and (d) 5 to $3 \mathrm{ka}$ October, respectively. The months have been adjusted to the fixed-angular calendar.

\section{Summary and conclusion}

For several decades, the African humid period has provided a challenging palaeoclimate modelling target due to the difficulties in reproducing the magnitude and extent of wet conditions suggested by proxy data and the evidence for nonlinear behaviour during the transitions into and out of the AHP, both of which have been ascribed to the impact of land surface feedbacks on the monsoon. More recently, Shanahan et al. (2015) argued that the end of the AHP was timetransgressive rather than uniformly abrupt, and that regionalscale differences in the seasonality of monsoon rains could explain this variable monsoon response to the slowly evolving insolation forcing. Here, using high-resolution transient simulations of the last 7850 years from the comprehensive Earth system model MPI-ESM1.2, we calculated the spatial evolution of the AHP termination across north Africa. Despite some differences in the spatial extent and magnitude of precipitation changes during the AHP, particularly over the Sahara, our experiment is in broad agreement with the spatial patterns in the timing of the AHP end in the proxy data. In general, the end of the AHP began earlier in the north than in the south and occurred earlier in the east than in the west.

As north Africa is not only affected by the (tropical) monsoon circulation but also by extratropical troughs penetrating into lower latitudes and transporting moisture towards the Sahara, the continent regionally faces very different seasonal cycles in rainfall. We hypothesized that the (seasonal) changes in the insolation forcing throughout the Holocene affect these "key players" and the regional rainfall regimes differently, causing the spatial variations in the timing of the end of the AHP. Based on the seasonal rainfall cycle, five regions were distinguished here (see Fig. 7a).

a. Equatorial zone (yellow) region with year-round precipitation. In the eastern part of this zone, reconstructions and model results deviate. The AHP end is rather patchy, which may be related to the fact that the signal is very weak and not robust. Furthermore, the orography in this zone is very complex and under-represented in the model. A distinct reason for the pattern in AHP end cannot be derived from the model. In the western (coastal) part, rainfall increases during the Holocene due to the southward shift of the monsoon rain belt. The AHP ends late or is still present in preindustrial times. This contrasting trend may partly be related to the fact that rainfall in western equatorial Africa is the result of complex regional and remote interactions between the tropical oceans, the orography, and the atmospheric circulation. In present-day observations, the region shows the highest rainfall rates in north Africa and maximum moisture recycling ratios. The seasonal precipitation cycle is related to the insolation changes, but the monsoonal cycle explains only part of the regional climate variability (cf. Dezfuli, 2017, and references therein).

b. Main monsoon domain (orange) region that is solely affected by the summer monsoon. The AHP end in the main monsoon domain can fully be explained by the re- 
treat of the west African summer monsoon $(r=0.84)$. The monsoon circulation is gradually weakening and shifting southwards during the Holocene. As the monsoon rainband is meridionally tilted, the rainband stays longer in the western part than in the eastern part, imprinting the east-west gradient on the AHP end.

c. Westernmost Sahara (red) region with summer monsoon rainfall and rainfall related to extratropical troughs. During early- and mid-Holocene, the monsoon season is prolonged to September, leading to strong moisture supply in the western coastal area. Due to the shift in perihelion towards autumn, the maintenance of the monsoonal circulation pattern into October is favoured at mid-Holocene. The upper-level westerlies intensify during the Holocene, providing condition that foster extratropical-tropical interactions. Due to the interplay of a still strong monsoon and a strengthened subtropical jet, rain events at the coast increase from 7 to $5 \mathrm{ka}$, leading to a delay in the AHP end. Afterwards the circulation systems become decoupled and the extratropicaltropical interaction reduces.

d. North-western Sahara (green) region with autumn and wintertime precipitation, strongly effected by ETIs. The number of rain events decreases gradually during the Holocene (here since $7 \mathrm{ka}$ ) as the moisture supply is reduced due to the equatorward retreat of the monsoon system. The interaction of the extratropical and the tropical circulation gets weaker, since the circulation systems get more and more decoupled. As the preconditions for the formation of rain events are getting more favourable closer to the western coast, rain events can "survive" longer in that region. The rainfall surplus due to ETIs vanished first in the central northern Sahara and than in the western part, leading to a slight gradient in the AHP end in the western Sahara.

e. Eastern Sahara (blue) region with (little) wintertime precipitation. This region neither profits from monsoonal rainfall nor from the ETIs; precipitation is rare and does not change much during the Holocene. According to the model, no humid phase occurs during the entire Holocene in this region.

We explain the reconstructed time-transgressive end of the African humid period based on a transient experiment performed in a comprehensive Earth system model. The model results clearly show that the regionally different seasonality affects the response of the rainfall to the Holocene insolation change. The mid-Holocene atmospheric conditions are optimal for the initiation of rainfall events in the western Sahara via extratropical-tropical interactions, as the monsoon season is prolonged and the subtropical westerly jet can reach far to the south during the late summer and autumn seasons. In the course of the Holocene, the monsoon weakens and moves southward while the upper level subtropical westerly jet intensifies. Both changes compensate each other for several thousand years until the extratropical and tropical circulation become decoupled. Due to this interaction, the AHP end is delayed in the western Sahara. Humid conditions are maintained longest at the southwestern Saharan coast, where the combined effect of enhanced monsoon and increased extratropical trough occurrence favours precipitation most (at least up to $5 \mathrm{ka}$ ). In the main monsoon region the asynchronous end of the AHP is solely controlled by the retreating monsoon system. As the monsoon rainband is tilted zonally, the AHP ends earlier in the east than in the west (on the same latitude). Regions in the Sahara to which the moisture is transported neither by extratropical troughs nor by the monsoon flow, show an AHP end directly at the beginning of the simulations (i.e. there is no AHP).

Our results show that the analysis of rainfall trends in north Africa should not be limited to the monsoon season. Insolation changes affect the atmospheric circulation year-round and the impact of the non-monsoonal processes may vary with time, also with respect to their contribution to the annual rainfall signal. Thus, non-monsoonal processes may be important in other climate states, even if they are less relevant in today's climate. Our results furthermore raise the question of whether the abrupt transition into the drier state recorded in sediment cores off the western Saharan coast must also be interpreted in the context of a decoupling of the extratropical and tropical atmospheric circulation somewhere during the mid- to late Holocene that may have led to a regionally relatively fast termination of the humid period. 


\section{Appendix A: Circulation anomalies associated with strong rain events in the Sahara}

Figures A1-A3 show the $7 \mathrm{ka}$ September and October mean atmospheric circulation in $300 \mathrm{hPa}$ (tropical and subtropical jet level), $600 \mathrm{hPa}$ (AEJ level), and $850 \mathrm{hPa}$ (monsoon level) and the anomalies in this circulation coinciding with strong rain events (composite mean).

Heavy rainfall events in the coastal area characterize the September mean moisture flux during $7 \mathrm{ka}$. The composite mean of all rain events $\left(>4 \mathrm{~mm} \mathrm{~d}^{-1}\right)$ differs only slightly from the monthly mean flow, showing just a little increased moisture flux convergence in Mauritania and at the Moroccan coast (cf. Fig. 11). The moisture flux is determined by a strong easterly wind band between 20 and $30^{\circ} \mathrm{N}$, which can partly be explained by a tropical easterly jet extending further north (Fig. A1). On the other hand, a cold air anomaly directly at the coast (centre at $20^{\circ} \mathrm{W}$ and $20^{\circ} \mathrm{N}$ ), which reaches far into the troposphere, leads to a slight northward inclination of the African easterly jet in its outflow (Fig. A2). This favours vertical uplift at the coast and gives the atmospheric flow a small southerly wind component at the jet level. The cold air anomaly associated with rain events at the coast furthermore causes a slightly stronger and more northerly extending monsoon flow, which has a pronounced, albeit regionally confined, south wind component (Fig. A3).

In contrast, October rain events at the coast coincide with a pronounced monsoon-like moisture flux onto the continent in the region $8-18^{\circ} \mathrm{N}$ (west of $5^{\circ} \mathrm{W}$ ) turning to the north and resulting in an intensified moisture convergence at the coast (north of $18^{\circ} \mathrm{N}$ ) compared to the mean state. This southerly wind anomaly runs through the entire troposphere. In upper levels (here: $300 \mathrm{hPa}$, Fig. 12), a Rossby-wave-like anomaly with higher geopotential above the northwestern Sahara and lower geopotential above the Atlantic leads to an anticyclonic flow (centre ca. $27^{\circ} \mathrm{N}, 5^{\circ} \mathrm{W}$ ) triggering south wind along the coast. This temperature anomaly furthermore results in a tilting of the African easterly jet axis towards the Canary Islands so that anomalous southerly winds can establish also at this level. The low-level atmospheric flow is characterized by a monsoon-like inflow and a northward flow along the coast. To summarize, the atmospheric conditions for heavy rain events in the coastal area are part of the normal latemonsoon circulation during September. During October, this circulation is maintained when abundant rain falls in this region.

Strong rain events in the western Sahara are associated with a strong meridional moisture transport from low latitudes to the Mediterranean Sea and an abnormally strong monsoon-like inflow from the Atlantic stretching deep onto the continent. The moisture flux converges distinctly over the western Sahara and diverges slightly more intensively over the eastern Sahara and along the western coast compared to the mean (cf. Fig. 11). This pattern is at least partly related to the changes in the African easterly jet (Fig. A2)
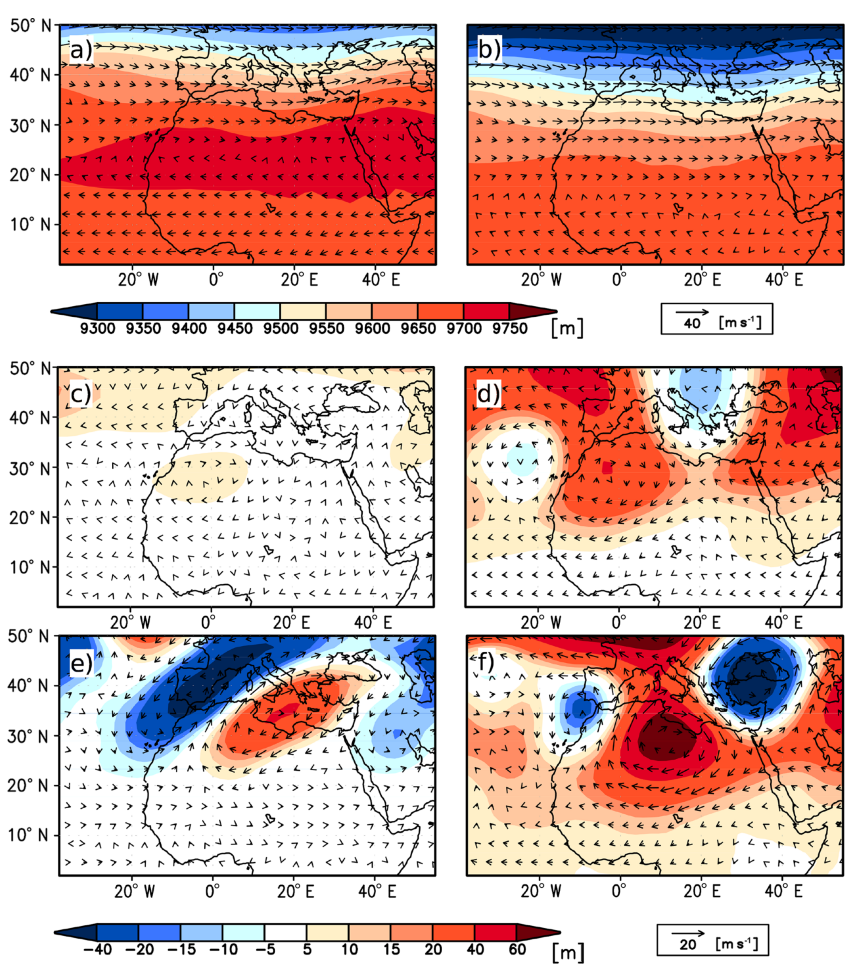

Figure A1. Monthly mean geopotential height at $300 \mathrm{hPa}(\mathrm{m}$, shaded) and wind at $300 \mathrm{hPa}\left(\mathrm{m} \mathrm{s}^{-1}\right.$, vector) for (a) $7 \mathrm{ka}$ September and (b) $7 \mathrm{ka}$ October. (c, d) Differences in $300 \mathrm{hPa}$ geopotential height $\left(\mathrm{m}\right.$, shaded) and $300 \mathrm{hPa}$ wind $\left(\mathrm{m} \mathrm{s}^{-1}\right.$, vector) between the composite of all rain events occurring in the coastal area (15$11^{\circ} \mathrm{W}, 20-25^{\circ} \mathrm{N}$ ) and the monthly mean flow for (c) $7 \mathrm{ka}$ September, (d) $7 \mathrm{ka}$ October; (e, f) differences between the composite of all rain events in the western Sahara $\left(20-35^{\circ} \mathrm{N}, 10^{\circ} \mathrm{W}-10^{\circ} \mathrm{E}\right)$ and the monthly mean flow for (e) $7 \mathrm{ka}$ September and (f) $7 \mathrm{ka}$ October. The months have been adjusted to the fixed-angular calendar.

that is substantially reduced in its outflow domain, diminishing the moisture transport to the coast. Lower geopotential height along the northwestern coast leads to a cyclonic circulation anomaly with strong south winds around $0^{\circ} \mathrm{E}$. This anomaly extends through the entire troposphere and results in a monsoon-like inflow (Fig. A3) and southwest winds in $850 \mathrm{hPa}$, which reaches further inland than in the case of coastal rain events. In the upper levels (Fig. A1), a large trough forms, penetrating deep into the subtropics, portraying the classical pattern of the extratropical-tropical interaction. The atmospheric circulation anomaly for Sahara rain events is similar in September and October, although it is more pronounced during October. The region of moisture convergence fits very well to the region in which the AHP end is delayed (i.e. later than $8 \mathrm{ka}$ ). On the other hand, the regions in the Sahara to which the moisture is transported neither by extratropical troughs nor by the monsoon flow, show an AHP end directly at the beginning of the simulations (i.e. there is no AHP). 

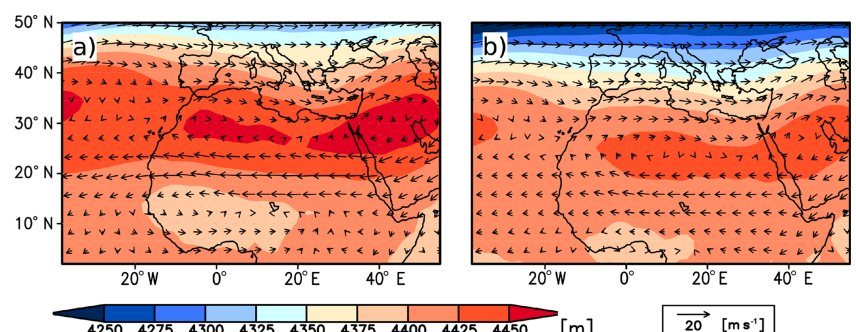

$\begin{array}{lllllllll}4250 & \frac{1}{4275} & \frac{1}{4300} & \frac{1}{4325} & \frac{1}{4350} & \frac{1}{4375} & \frac{1}{4400} & \frac{1}{4425} & \frac{1}{4450}\end{array}$ [m]
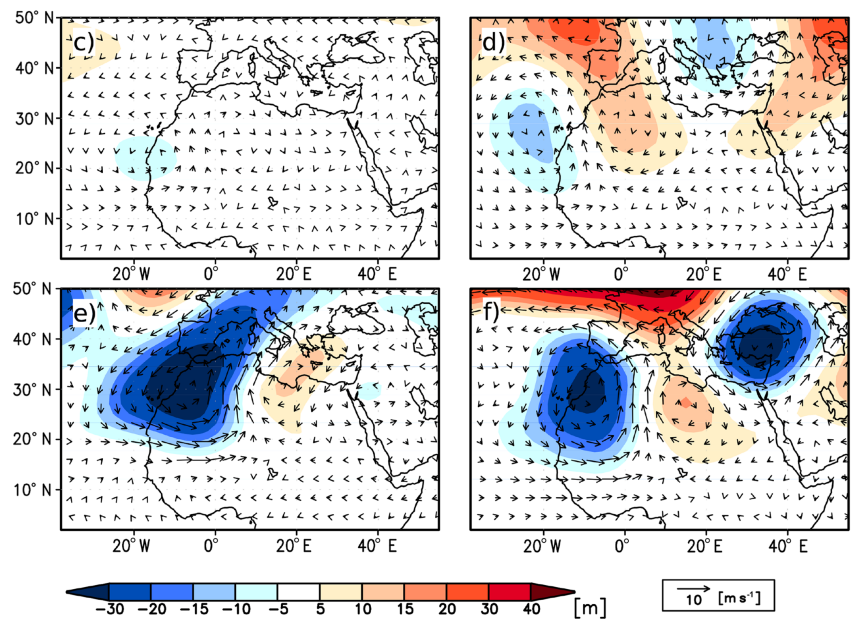

Figure A2. Monthly mean geopotential height at $600 \mathrm{hPa}(\mathrm{m}$, shaded) and wind at $600 \mathrm{hPa}\left(\mathrm{m} \mathrm{s}^{-1}\right.$, vector) for (a) $7 \mathrm{ka}$ September and (b) $7 \mathrm{ka}$ October. (c, d) Differences in $600 \mathrm{hPa}$ geopotential height $\left(\mathrm{m}\right.$, shaded) and $600 \mathrm{hPa}$ wind $\left(\mathrm{m} \mathrm{s}^{-1}\right.$, vector) between the composite of all rain events occurring in the coastal area (15$11^{\circ} \mathrm{W}, 20-25^{\circ} \mathrm{N}$ ) and the monthly mean flow for (c) $7 \mathrm{ka}$ September, (d) $7 \mathrm{ka}$ October; (e, f) differences between the composite of all rain events in the western Sahara $\left(20-35^{\circ} \mathrm{N}, 10^{\circ} \mathrm{W}-10^{\circ} \mathrm{E}\right)$ and the monthly mean flow for (e) $7 \mathrm{ka}$ September and (f) $7 \mathrm{ka}$ October. The months have been adjusted to the fixed-angular calendar.
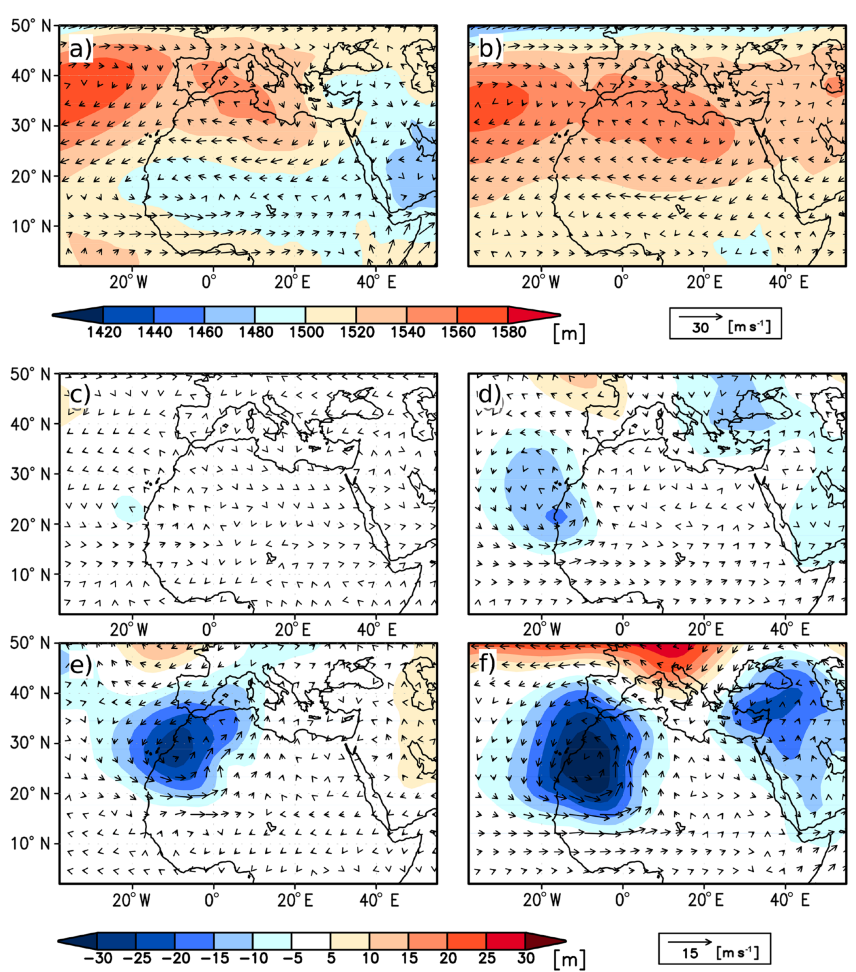

Figure A3. Monthly mean geopotential height at $850 \mathrm{hPa}(\mathrm{m}$, shaded) and wind at $850 \mathrm{hPa}\left(\mathrm{m} \mathrm{s}^{-1}\right.$, vector) for (a) $7 \mathrm{ka}$ September and (b) $7 \mathrm{ka}$ October. (c, d) Differences in $850 \mathrm{hPa}$ geopotential height $\left(\mathrm{m}\right.$, shaded) and $850 \mathrm{hPa}$ wind $\left(\mathrm{m} \mathrm{s}^{-1}\right.$, vector) between the composite of all rain events occurring in the coastal area (15$11^{\circ} \mathrm{W}, 20-25^{\circ} \mathrm{N}$ ) and the monthly mean flow for (c) $7 \mathrm{ka}$ September, (d) $7 \mathrm{ka}$ October; and (e, f) differences between the composite of all rain events in the western Sahara $\left(20-35^{\circ} \mathrm{N}, 10^{\circ} \mathrm{W}-10^{\circ} \mathrm{E}\right)$ and the monthly mean flow for (e) $7 \mathrm{ka}$ September and (f) $7 \mathrm{ka} \mathrm{Oc}$ tober. The months have been adjusted to the fixed-angular calendar. 


\section{Appendix B}

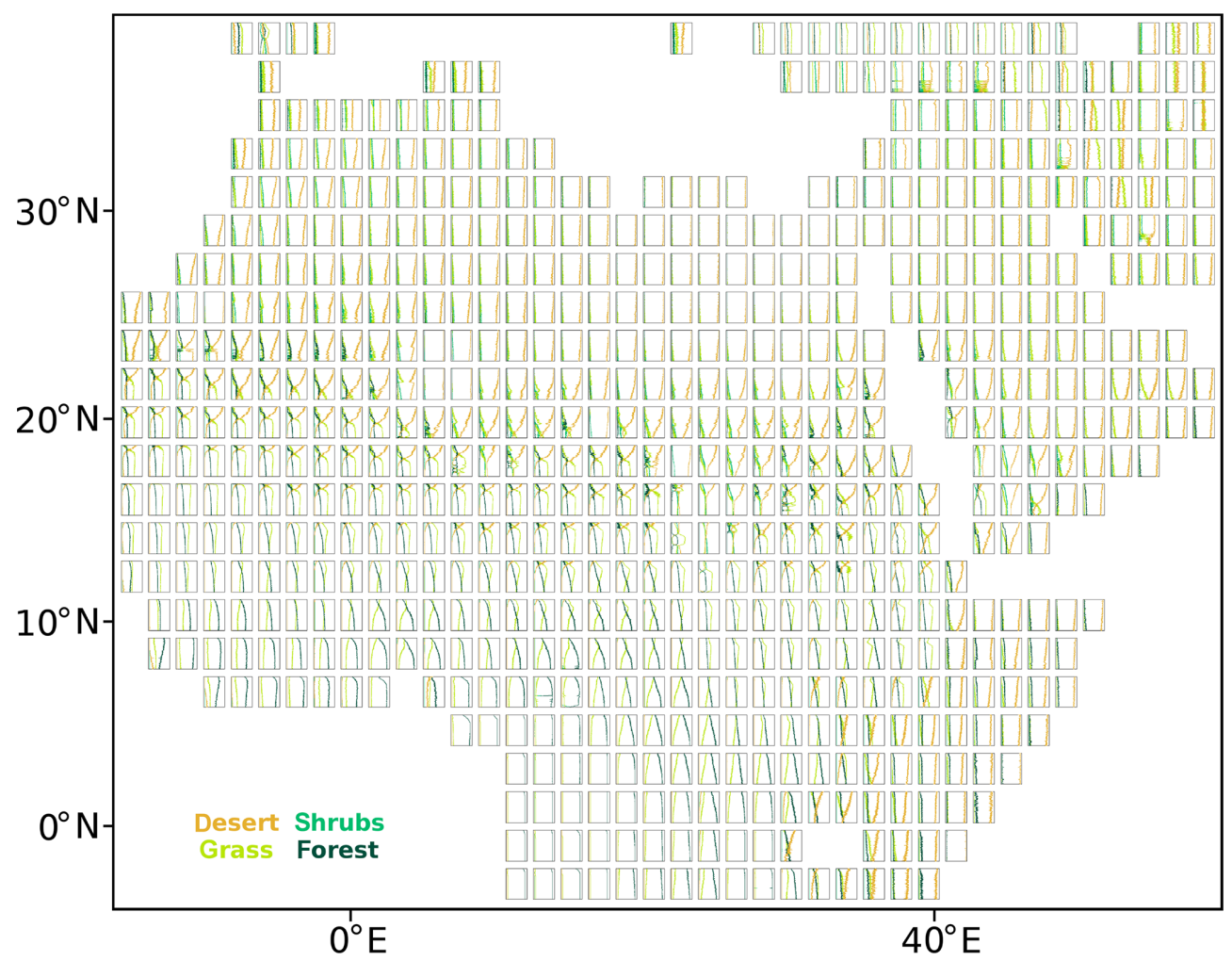

Figure B1. Simulated transient change in main PFT cover fraction (i.e. desert, grass, shrubs, and forest fraction) during the last 7850 years in each north African grid cell. The $x$ axis of each individual plot displays the cover fraction ranging from 0 (left corner) to 1 (right corner); the $y$ axis displays the time ranging from $8 \mathrm{ka}$ (bottom) to PI (top). A high-resolution version of this plot is provided in the Supplement. 
Code and data availability. Relevant data, scripts used for the analysis, and supplementary information that may be useful in reproducing the authors' work will be archived by the Max Planck Institute for Meteorology and are accessible without any restrictions (http://hdl.handle.net/21.11116/0000-0003-F299-F, last access: 1 November 2019; MPG.PuRe, 2019).

A table containing a list of all records with their references and the inferred AHP end and difference to the synthesis published in Shanahan et al. (2015) is available in the Supplement.

The Biome6000 pollen-based biome reconstructions (Harrison, 2017) can be downloaded from: https://doi.org/10.17864/1947.99.

The precipitation reconstructions used in this study are part of the supplement of the article by Bartlein et al. (2011).

The PMIP3 simulations of MPI-ESM-T63, MIROC-ESM, and HadGEM2-ESM can be downloaded from the Earth System Grid Federation. Please see the list in the archive to this article for simulation IDs and further information.

Supplement. The supplement related to this article is available online at: https://doi.org/10.5194/cp-16-117-2020-supplement.

Author contributions. AD and TS wrote the article; SL performed the simulations; MC and AD planned the study. All authors discussed the analysis and the article.

Competing interests. The authors declare that they have no conflict of interest.

Acknowledgements. This work contributes to the project PalMod, funded by the German Federal Ministry of Educaion and Research (BMBF), Research for Sustainability initiative FONA, https://www.fona.de, last access: 8 February 2019) and the JPI-Belmont PACMEDY project (grant no. BMBF 01LP1607B-CLIMPRE_PACMEDY). Anne Dallmeyer was financed by PalMod. We thank Thomas Kleinen (MPI-M) for his helpful comments on an earlier version of this article. We would like to thank the editor Ran Feng for kindly handling his paper and the two anonymous referees for their constructive comments which helped to improve the article. We acknowledge the World Climate Research Programme's Working Group on Coupled Modelling, which is responsible for CMIP, and we thank the climate modelling groups (Met Office Hadley Centre; Japan Agency or Marine-Earth Science and Technology, Atmosphere and Ocean Research Institute (University of Tokyo); and the National Institute for Environmental Studies) for producing and making available their model output within PMIP3. For CMIP, the US Department of Energy's Program for Climate Model Diagnosis and Intercomparison provides coordinating support and led the development of software infrastructure in partnership with the Global Organization for Earth System Science Portals.
Financial support. This research has been supported by the German Federal Ministry of Education and Research (BMBF) (PALMOD (project no. 01LP1506A)) and the JPI-Belmont PACMEDY project (grant no. 01LP1607B-CLIMPRE_PACMEDY).

The article processing charges for this open-access publication were covered by the Max Planck Society.

Review statement. This paper was edited by Ran Feng and reviewed by two anonymous referees.

\section{References}

Adkins, J., deMenocal, P., and Eshel, G.: The "African Humid Period" and the record of marine upwelling from excess ${ }^{230} \mathrm{Th}$ in ODP Hole 658C, Paleoceanography, 21, PA4203, https://doi.org/10.1029/2005PA001200, 2006.

Bader, J., Jungclaus, J., Krivova, N., Lorenz, S., Maycock, A., Raddatz, T., Schmidt, H., Toohey, M., Wu, C.-J., and Claussen, M.: Global temperature modes shed light on the Holocene temperature conundrum, Nat. Commun., submitted, 2019.

Bartlein, P. J. and Shafer, S. L.: Paleo calendar-effect adjustments in time-slice and transient climate-model simulations (PaleoCalAdjust v1.0): impact and strategies for data analysis, Geosci. Model Dev., 12, 3889-3913, https://doi.org/10.5194/gmd-123889-2019, 2019.

Bartlein, P. J., Harrison, S. P., Brewer, S., Connor, S., Davis, B. S. A., Gajewski, K., Guiot, J., Harrison-Prentice, T. I., Henderson, A., Peyron, O., Prentice, J. C., Scholze, M., Seppä, H., Shuman, B., Sugita, S., Thompson, R. S., Viau, A. E., Williams, J., and $\mathrm{Wu}, \mathrm{H}$.: Pollen-based continental climate reconstructions at 6 and 21 ka: A global synthesis, Clim. Dynam., 37, 775-802, https://doi.org/10.1007/s00382-010-0904-1, 2011.

Berger, A. L.: Long term variations of daily insolation and quaternary climatic changes, J. Atmos. Sci., 5, 2362-2367, 1978.

Bosmans, J. H. C., Drijfhout, S. S., Tuenter, E., Lourens, L. J., Hilgen, F. J., and Weber, S. L.: Monsoonal response to midholocene orbital forcing in a high resolution GCM, Clim. Past, 8, 723-740, https://doi.org/10.5194/cp-8-723-2012, 2012.

Bosmans, J., Drijfhout, S., Tuenter, E., Hilgen, F., and Lourens, L.: Response of the North African summer monsoon to precession and obliquity forcings in the EC-Earth GCM, Clim. Dynam., 44, 279-297, https://doi.org/10.1007/s00382-014-2260-z, 2014.

Braconnot, P., de Noblet, N., and Ramstein, G.: Mid-Holocene and last glacial maximum African monsoon changes as simulated within the Paleoclimate Modelling Intercomparison Project, Global Planet. Change, 26, 51-66, 2000.

Braconnot, P., Otto-Bliesner, B., Harrison, S., Joussaume, S., Peterchmitt, J.-Y., Abe-Ouchi, A., Crucifix, M., Driesschaert, E., Fichefet, Th., Hewitt, C. D., Kageyama, M., Kitoh, A., Loutre, M.-F., Marti, O., Merkel, U., Ramstein, G., Valdes, P., Weber, L., Yu, Y., and Zhao, Y.: Results of PMIP2 coupled simulations of the Mid-Holocene and Last Glacial Maximum Part 2: feedbacks with emphasis on the location of the ITCZ and mid- and high latitudes heat budget, Clim. Past, 3, 279-296, https://doi.org/10.5194/cp-3-279-2007, 2007. 
Braconnot, P., Marzin, C., Grégoire, L., Mosquet, E., and Marti, O.: Monsoon response to changes in Earth's orbital parameters: comparisons between simulations of the Eemian and of the Holocene, Clim. Past, 4, 281-294, https://doi.org/10.5194/cp-4-281-2008, 2008.

Braconnot, P., Harrison, S., Bartlein, P., Masson-Delmotte, V., AbeOuchi, A., Otto-Bliesner, B., and Zhao, Y.: Evaluation of climate models using palaeoclimatic data, Nat. Clim. Change, 2, 417424, https://doi.org/10.1038/nclimate1456, 2012.

Braconnot, P., Zhu, D., Marti, O., and Servonnat, J.: Strengths and challenges for transient Mid- to Late Holocene simulations with dynamical vegetation, Clim. Past, 15, 997-1024, https://doi.org/10.5194/cp-15-997-2019, 2019.

Brovkin, V., Raddatz, T., Reick, C. H., Claussen, M., and Gayler, V.: Global biogeophysical interactions between forest and climate, Geophys. Res. Lett., 36, L07405, https://doi.org/10.1029/2009GL037543, 2009.

Brovkin, V., Lorenz, S., Raddatz, T., Ilyina, T., Stemmler, I., Toohey, M., and Claussen, M.: What was the source of the atmospheric $\mathrm{CO}_{2}$ increase during the Holocene?, Biogeosciences, 16, 2543-2555, https://doi.org/10.5194/bg-16-2543-2019, 2019.

Claussen, M. and Gayler, V.: The Greening of the Sahara during the Mid-Holocene: Results of an Interactive Atmosphere-Biome Model, Global Ecol. Biogeogr., 6, 369-377, 1997.

Claussen, M., Kubatzki, C., Brovkin, V., Ganopolski, A., Hoelzmann, P., and Pachur, H. J: Simulation of an abrupt change in Saharan vegetation in the mid-Holocene, Geophys. Res. Lett., 26, 2037-2040, 1999.

Claussen, M., Dallmeyer, A., and Bader, J.: Theory and modeling of the African humid period and the green Sahara, Oxford Research Encyclopedia of Climate Science, https://doi.org/10.1093/acrefore/9780190228620.013.532, 2017.

Cohen, J.: A coefficient of agreement for nominal scales, Educ. Psychol. Meas., 20, 37-46, 1960.

Collins, J., Prange, M., Caley, T., and Schefuß, E.: Rapid termination of the African Humid Period triggered by northern high-latitude cooling, Nat. Commun., 8, 1372, https://doi.org/10.1038/s41467-017-01454-y, 2017.

COHMAP Members: Climatic changes of the last 18,000 years: Observations and model simulations, Science, 241, 1043-1052, 1988.

Cook, K. H.: Generation of the African easterly jet and its role in determining west African precipitation, J. Climate, 12, 1165-1184, 1999.

Dallmeyer, A., Claussen, M., and Brovkin, V.: Harmonising plant functional type distributions for evaluating Earth system models, Clim. Past, 15, 335-366, https://doi.org/10.5194/cp-15-3352019, 2019.

deMenocal, P. B. and Tierney, J. E.: Green Sahara: African Humid Periods Paced by Earth's Orbital Changes, Nature Education Knowledge, 3, 12, 1-6, 2012.

deMenocal, P. B., Ortiz, J., Guilderson, T., Adkins, J., Santhein, M., Baker, L., and Yarusinsky, M.: Abrupt onset and termination of the African Humid Period: Rapid climate responses to gradual insolation forcing, Quaternary Sci. Rev., 19, 347-361, 2000.

Dezfuli, A.: Climate of Western and Central Equatorial Africa, Oxford Research Encyclopedia of Climate Science, https://doi.org/10.1093/acrefore/9780190228620.013.511, 2017.
Egerer, S., Claussen, M., and Reick, C.: Rapid increase in simulated North Atlantic dust deposition due to fast change of northwest African landscape during the Holocene, Clim. Past, 14, 10511066, https://doi.org/10.5194/cp-14-1051-2018, 2018.

Foody, G. M.: Status of land cover classification accuracy assessment, Remote Sens. Environ., 80, 185-201, 2002.

Fröhlich, L., Knippertz, P., Fink, A. H., and Hohberger, E.: An objective climatology of tropical plumes, J. Climate, 26, 50445060, 2013.

Gaetani, M., Messori, G., Zhang, Q., Flamant C., and Pausata, F. S.: Understanding the Mechanisms behind the Northward Extension of the West African Monsoon during the Mid-Holocene, J. Climate, 30, 7621-7642, https://doi.org/10.1175/JCLI-D-160299.1, 2017.

Geb, M.: Factors favouring precipitation in North Africa: Seen from the viewpoint of present-day climatology, Global Planet. Change, 26, 85-96, 2000.

Goll, D. S., Brovkin, V., Liski, J., Raddatz, T., Thum, T., and ToddBrown, K. E. O.: Strong dependence of $\mathrm{CO}_{2}$ emissions from anthropogenic land cover change on initial land cover and soil carbon parametrization, Global Biogeochem. Cy., 29, 1511-1523, https://doi.org/10.1002/2014gb004988, 2015.

Grist, J. P. and Nicholson, S. E.: A study of the dynamic factors influencing the rainfall variability in the west african sahel, J. Climate, 14, 1337-1359, 2001.

Hagemann, S. and Stacke, T.: Impact of the soil hydrology scheme on simulated soil moisture memory, Clim. Dynam., 44, 17311750, https://doi.org/10.1007/s00382-014-2221-6, 2015.

Harrison, S.: BIOME 6000 DB classified plotfile version 1, University of Reading, Dataset, https://doi.org/10.17864/1947.99, 2017.

Harrison, S. P., Bartlein, P. J., Brewer, S., Prentice, I. C., Boyd, M., Hessler, I., Holmgren, K., Izumi, K., and Willis, K.: Climate model benchmarking with glacial and mid-Holocene climates, Clim. Dynam., 43, 671-688, https://doi.org/10.1007/s00382013-1922-6, 2014.

Hély, C., Lézine, A.-M., and contributors, A.: Holocene changes in African vegetation: tradeoff between climate and water availability, Clim. Past, 10, 681-686, https://doi.org/10.5194/cp-10-6812014, 2014.

Hoelzmann, P., Jolly, D., Harrison, S. P., Laarif, F., Bonnefille, R., and Pachur, H.-J.: Mid-Holocene land-surface conditions in northern Africa and the Arabian Peninsula: A data set for the analysis of biogeophysical feedbacks in the climate system, Global Biogeochem. Cy., 12, 35-51, 1998.

Hoelzmann, P., Kruse, H.-J., and Rottinger, F.: Precipitation estimates for the eastern Saharan palaeomonsoon based on a water balance model of the West Nubian Palaeolake Basin, Global Planet. Change, 26, 105-120, 2000.

Hoelzmann, P., Keding, B., Berke, H., Kröpelin, S., and Kruse, H. J.: Environmental change and archaeology: lake evolution and human occupation in the Eastern Sahara during the Holocene, Palaeogeogr. Palaeocl., 169, 193-217, 2002.

Hurtt, G. C., Chini, L. P., Frolking, S., Betts, R. A., Feddema, J., Fischer, G., Fisk, J. P., Hibbard, K., Houghton, R. A., Janetos, A., Jones, C. D., Kindermann, G., Kinoshita, T., Goldewijk, K. K., Riahi, K., Shevliakova, E., Smith, S., Stehfest, E., Thomson, A., Thornton, P., van Vuuren, D. P., and Wang, Y. P.: Harmonization of land-use scenarios for the period 1500-2100: 600 years of global gridded annual land-use transitions, wood har- 
vest, and resulting secondary lands, Climatic Change, 109, 117161, https://doi.org/10.1007/s10584-011-0153-2, 2011.

Ilyina, T., Six, K., Segschneider, J., Maier-Reimer, E., Li, H., and Núñez-Riboni, I.: Global ocean biogeochemistry model HAMOCC: Model architecture and performance as component of the MPI-Earth System Model in different CMIP5 experimental realizations, J. Adv. Model. Earth Sy., 5, 287-315, https://doi.org/10.1029/2012MS000178, 2013.

Janiga, M. A. and Thorncroft, C. D.: The Infuence of African Easterly Waves on Convection over Tropical Africa and the East Atlantic, Mon. Weather Rev., 144, 171-192, 2016.

Jolly, D., Prentice, I. C., Bonneille, R., Ballouche, A., Bengo, M., Brenac, P., Buchet, G., Burney, D., Cazet, J.-P., Cheddadi, R., Edorh, T., Elenga, H., Elmoutaki, S., Guiot, J., Laarif, F., Lamb, H., Lezine, A.-M., Maley, J., Mbenza, M., Peyron, O., Reille, M., Reynaud-Farrera, I., Riollet, G., Ritchie, J. C., Roche, E., Scott, L., Ssemmanda, I., Straka, H., Umer, M., Van Campo, E., Vilimumbalo, S., Vincens, A., and Waller, M.: Biome reconstruction from pollen and plant macrofossil data for Africa and the Arabian peninsula at 0 and 6000 years, J. Biogeogr., 25, 1007-1027, 1998.

Joussaume, S., Taylor, K. E., Braconnot, P., Mitchell, J. F. B., Kutzbach, J. E., Harrison, S. P., Prentice, I. C., Broccoli, A. J., Abe-Ouchi, A., Bartlein, P. J., Bonfiels, C., Dong., B., Guiot, J., Herterich, K., Hewit, C. D., Jolly, D., Kim, J. W., Kislov, A., Kitoh, A., Loutre, M. F., Masson, V., McAvaney, B., McFarlane, N., deNoblet, N., Peltier, W. R., Peterschmitt, J. Y., Pollard, D., Rind, D., Royer, J. F., Schlesinger, M. E., Syktus, J., Thompson, S., Valdes, P., Vettoretti, G., Webb, R. S., and Wyputta, U.: Monsoon changes for 6000 years ago: Results of 18 simulations from the Paleoclimate Modeling Intercomparison Project (PMIP), Geophys. Res. Lett., 26, 859-862, 1999.

Jungclaus, J. H., Fischer, N., Haak, H., Lohmann, K., Marotzke, J., Matei, D., Mikolajewicz, U., Notz, D., and von Storch, J. S.: Characteristics of the ocean simulations in the Max Planck Institute Ocean Model (MPIOM) the ocean component of the MPI-Earth system model, J. Adv. Model. Earth Sy., 5, 422-446, https://doi.org/10.1002/jame.20023, 2013.

Knippertz, P.: Tropical-extratropical interactions causing precipitation in Northwest Africa: Statistical analysis and seasonal variations, Mon. Weather Rev., 131, 3069-3076, 2003.

Knippertz, P.: Tropical-extratropical interactions related to upperlevel troughs at low latitudes, Dynam. Atmos. Oceans, 43, 3662, 2007.

Knippertz, P. and Martin, J. E.: Tropical plumes and extreme precipitation in subtropical and tropical West Africa, Q. J. Roy. Meteor. Soc., 131, 2337-2365, https://doi.org/10.1256/qj.04.148, 2005.

Knippertz, P., Fink, A. H., Reiner, A., and Speth, P.: Three late summer/early autumn cases of tropical-extratropical interactions causing precipitation in Northwest Africa, Mon. Weather Rev., 131, 116-135, 2003.

Köhler, P.: Interactive comment on "What was the source of the atmospheric $\mathrm{CO}_{2}$ increase during the Holocene?" by Victor Brovkin et al., Biogeosciences Discuss., C1-C6, https://doi.org/10.5194/bg-2019-64-SC1, 2019.

Krinner, G., Lezine, A. M., Braconnot, P., Sepulchre, P., Ramstein, G., Grenier, C., and Gouttevin, I.: A reassessment of lake and wetland feedbacks on the North African
Holocene climate, Geophys. Res. Lett., 39, L07701, https://doi.org/10.1029/2012GL050992, 2012.

Krivova, N. A., Solanki, S. K., and Unruh, Y. C.: Towards a long-term record of solar total and spectral irradiance, J. Atmos. Sol.-Terr. Phy., 73, 223-234, https://doi.org/10.1016/j.jastp.2009.11.013, 2011.

Kröpelin, S., Verschuren, D., Lézine, A. M., Eggermont, H., Cocquyt, C., Francus, P., Cazet, J. P., Fagot, M., Rumes, B., Russell, J. M., Darius, F., Conley, D. J., Schuster, M., von Suchodoletz, H., and Engstrom, D. R.: Climate-driven ecosystem succession in the Sahara: The past 6000 years, Science, 320, 765-768, 2008.

Kuper, R. and Kröpelin, S.: Climate-controlled Holocene occupation of the Sahara: Motor of Africa's evolution, Science, 313, 803-807, 2006.

Kutzbach, J. E.: Monsoon climate of the early Holocene: Climate experiment with the Earth's orbital parameters for 9000 years ago, Science, 214, 59-61, 1981.

Kutzbach, J. E. and Liu, Z.: Response of the African Monsoon to Orbital Forcing and Ocean Feedbacks in the Middle Holocene, Science, 278, 440-443, 1997.

Kutzbach, J. E., Chen, G., Cheng, H., Edwards, L. R., and Liu, Z.: Potential role of winter rainfall in explaining increased moisture in theMediterranean and Middle East during periods of maximum orbitally-forced insolation seasonality, Clim. Dynam., 42, 1079-1095, 2014.

Lemburg, A., Bader, J., and Claussen, M.: Sahel rainfall Tropical Easterly Jet relationship on synoptic to intraseasonal time scales, Mon. Weather Rev., 147, 1733-1752, https://doi.org/10.1175/MWR-D-18-0254.1, 2019.

Levis, S., Bonan, G., and Bonfils, C.: Soil feedback drives the midHolocene North African monsoon northward in fully coupled CCSM2 simulations with a dynamic vegetation model, Clim. Dynam., 23, 791-802, 2004.

Lézine, A.-M., Hély, C., Grenier, C., Braconnot, P., and Krinner, G.: Sahara and Sahel vulnerability to climate changes, lessons from Holocene hydrological data, Quaternary Sci. Rev., 30, 30013012, 2011.

Liu, Z., Wang, Y., Gallimore, R., Notaro, M., and Prentice, I. C.: On the cause of abrupt vegetation collapse in North Africa during the Holocene: Climate variability vs. vegetation feedback, Geophys. Res. Lett., 33, L22709, https://doi.org/10.1029/2006GL028062, 2006.

Liu, Z., Wang, Y., Gallimore, R., Gasse, F., Johnson, T., deMenocal, P., Adkins, J., Notaro, M., Prentice, I. C., Kutzbach, J., Jacob, R., Behling, P., Wang, L., and Ong, E.: Simulating the transient evolution and abrupt change of Northern Africa atmosphere-oceanterrestrial ecosystem in the Holocene, Quaternary Sci. Rev., 26, 1818-1837, 2007.

Mauritsen, T., Bader, J., Becker, T., Behrens, J., Bittner, M., Brokopf, R., Brovkin, V., Claussen, M., Crueger, T., Esch, M., Fast, I., Fiedler, S., Popke, D., Gayler, V., Giorgetta, M., Goll, D., Haak, H., Hagemann, S., Hedemann, C., Hohenegger, C., Ilyina, T., Jahns, T., Jimenez Cuesta de la Otero, D., Jungclaus, J., Kleinen, T., Kloster, S., Kracher, D., Kinne, S., Kleberg, D., Lasslop, G., Kornblueh, L., Marotzke, J., Matei, D., Meraner, K., Mikolajewicz, U., Modali, K., Möbis, B., Müller, W., Nabel, J., Nam, C., Notz, D., Nyawira, S., Paulsen, H., Peters, K., Pincus, R., Pohlmann, H., Pongratz, J., Popp, M., Raddatz, T., Rast, S., Redler, R., Reick, C., Rohrschneider, T., 
Schemann, V., Schmidt, H., Schnur, R., Schulzweida, U., Six, K., Stein, L., Stemmler, I., Stevens, B., von Storch, J., Tian, F., Voigt, A., de Vrese, P., Wieners, K.-H., Wilkenskjeld, S., Roeckner, E., and Winkler, A.: Developments in the MPI-M Earth System Model version 1.2 (MPI-ESM1.2) and its response to increasing $\mathrm{CO}_{2}$, J. Adv. Model. Earth Sy., 11, 998-1038, https://doi.org/10.1029/2018MS001400, 2019.

McGee, D., deMenocal, P. B., Winckler, G., Stuut, J. B. W., and Bradtmiller, L. I.: The magnitude, timing and abruptness of changes in North African dust deposition over the last 20,000 yr, Earth Planet. Sc. Lett., 371-372, 163-176, 2013.

Meyer, D., Dimitriadou, E., Hornik, K., Weingessel A., and Leisch F.: e1071: Misc Functions of the Department of Statistics (e1071), TU Wien, R package version 1.6-4, available at: https://cran.r-project.org/src/contrib/Archive/e1071/ (last access: 14 December 2019), 2014.

MPG.PuRe, Publication Repository of the Max-Planck-Society, http://hdl.handle.net/21.11116/0000-0003-F299-F, last access: 16 December 2019.

Nicholson, S. E.: On the factors modulating the intensity of the tropical rainbelt over West Africa, Int. J. Climatol., 29, 673-689, 2009.

Nicholson, S. E. and Grist, J. P.: The Seasonal Evolution of the Atmospheric Circulation over West Africa and Equatorial Africa, J. Climate, 16, 1013-1030, 2003.

Patricola, C. M. and Cook, K. H.: Dynamics of the West African Monsoon under Mid-Holocene Precessional Forcing: Regional Climate Model Simulations, J. Climate, 20, 694-716, 2007.

Pausata, F., Messori, G., and Zhang, Q.: Impacts of dust reduction on the northward expansion of the African monsoon during the Green Sahara period, Earth Planet. Sc. Lett., 434, 298-307, https://doi.org/10.1016/j.epsl.2015.11.049, 2016.

Perez-Sanz, A., Li, G., González-Sampériz, P., and Harrison, S. P.: Evaluation of modern and mid-Holocene seasonal precipitation of the Mediterranean and northern Africa in the CMIP5 simulations, Clim. Past, 10, 551-568, https://doi.org/10.5194/cp-10551-2014, 2014.

Peyron, O., Jolly, D., Braconnot, P., Bonnefille, R., Guiot, J., Wirrmann, D., and Chalié, F.: Quantitative reconstructions of annual rainfall in Africa 6000 years ago: Model-data comparison, J. Geophys. Res., 111, D24110, https://doi.org/10.1029/2006JD007396, 2006.

Rachmayani, R., Prange, M., and Schulz, M.: North African vegetation-precipitation feedback in early and mid-Holocene climate simulations with CCSM3-DGVM, Clim. Past, 11, 175-185, https://doi.org/10.5194/cp-11-175-2015, 2015.

R Core Team: R: A language and environment for statistical computing, R Foundation for Statistical Computing, Vienna, Austria, available at: http://www.R-project.org/ (last access: 14 December 2019), 2014.

Reick, C. H., Raddatz, T., Brovkin, V., and Gayler, V.: The representation of natural and anthropogenic land cover change in MPI-ESM, J. Adv. Model. Earth Sy., 5, 1-24, https://doi.org/10.1002/jame.20022, 2013.

Renssen, H., Brovkin, V., Fichefet, T., and Goosse, H.: Holocene climate instability during the termination of the African Humid Period, Geophys. Res. Lett., 30, 1184, https://doi.org/10.1029/2002GL016636, 2003.
Roehrig, R., Bouniol, D., Guichard, F., Hourdin, F., and Redelsperger, J.-L.: The present and future of the West African monsoon: A process-oriented assessment of CMIP5 simulations along the AMMA transect, J. Climate, 26, 6471-6505, 2013.

Rossignol-Strick, M: Mediterranean Quaternary sapropels, an immediate response of the Africa monsoon to variation of insolation, Palaeogeogr. Palaeocl., 49, 237-263, 1985.

Shanahan, T. M., Mckay, N. P., Hughen, K. A., Overpeck, J. T., Otto-Bliesner, B., Heil, C. W., King, J., Scholz, C. A., and Peck, J.: The time-transgressive termination of the African humid period, Nat. Geosci., 8, 140-144, https://doi.org/10.1038/ngeo2329, 2015.

Skinner, C. B. and Diffenbaugh, N. S.: The contribution of African easterly waves to monsoon precipitation in the CMIP3 ensemble, J. Geophys. Res.-Atmos., 118, 3590-3609, https://doi.org/10.1002/jgrd.50363, 2013.

Skinner C. B. and Poulsen, C. J.: The role of fall season tropical plumes in enhancing Saharan rainfall during the African Humid Period, Geophys. Res. Lett., 43, 349-358, https://doi.org/10.1002/2015GL066318, 2016.

Skonieczny, C., McGee, D., Winckler, G., Bory, A., Bradtmiller, L. I., Kinsley, C. W., Polissar, P. J., De Pol-Holz, R., Rossignol, L., and Malaizé, B.: Monsoon-driven Saharan dust variability over the past 240,000 years, Science Advances, 5, eaav1887, https://doi.org/10.1126/sciadv.aav1887, 2019.

Stevens, B., Giorgetta, M., Esch, M., Mauritsen, T., Crueger, T., Rast, S., Salzmann, M., Schmidt, H., Bader, J., Block, K., Brokopf, R., Fast, I., Kinne, S., Kornblueh, L., Lohmann, U., Pincus, R., Reichler, T., and Roeckner, E.: Atmospheric component of the MPI-M Earth System Model: ECHAM6, J. Adv. Model. Earth Sy., 5, 146-172, https://doi.org/10.1002/jame.20015, 2013.

Street-Perrott, F. A., Marchand, D. S., Roberts, N., and Harrison, S. P.: Global Lake-Level Variations from 18,000 to 0 Years Ago: A Paleoclimatic Analysis. U.S. Department of Energy Technical Report 46, Washington, D.C. 20545. Distributed by National Technical Information Service, Springfield, VA 22161, 1989.

Su, H. and Neelin, J. D.: Dynamical mechanisms for African monsoon changes during the mid-Holocene, J. Geophys. Res., 110, D19105, https://doi.org/10.1029/2005JD005806, 2005.

Swann, A. L. S., Fung, I. Y., Liu, Y., and Chiang, J. C. H.: Remote vegetation feedbacks and the mid-Holocene Green Sahara, J. Climate, 27, 4857-4870, 2014.

Tang, G., Shafer, S. L., Bartlein, P., and Holman, J.: Effects of experimental protocol on global vegetation model accuracy: a comparison of simulated and observed vegetation patterns for Asia, Ecol. Model., 220, 1481-1491, 2009.

Thompson, A. J., Skinner, C. B., Poulsen, C. J., and Zhu, J.: Modulation of mid-Holocene African rainfall by dust aerosol direct and indirect effects, Geophys. Res. Lett., 46, 3917-3926, https://doi.org/10.1029/2018GL081225, 2019.

Tierney, J. E., Lewis, S. C., Cook, B. I., LeGrande, A. N., and Schmidt, G. A.: Model, proxy and isotopic perspectives on the East African Humid Period, Earth Planet. Sc. Lett., 307, 103112, 2011.

Tierney, J. E., Pausata, F. S. R., and deMenocal, P. B.: Rainfall regimes of the Green Sahara, Science Advances, 3, e1601503, https://doi.org/10.1126/sciadv.1601503, 2017.

Toohey, M. and Sigl, M.: Volcanic stratospheric sulfur injections and aerosol optical depth from 500 BCE to 1900 CE, Earth Syst. 
Sci. Data, 9, 809-831, https://doi.org/10.5194/essd-9-809-2017, 2017.

Tuenter, E., Weber, S. L., Hilgen, F. J., and Lourens, L. J.: The response of the African summer monsoon to remote and local forcing due to precession and obliquity, Global Planet. Change, 36, 219-235, 2003.

Vamborg, F. S. E., Brovkin, V., and Claussen, M.: The effect of a dynamic background albedo scheme on Sahel/Sahara precipitation during the mid-Holocene, Clim. Past, 7, 117-131, https://doi.org/10.5194/cp-7-117-2011, 2011.

Wang, B. and LinHo: Rainy season of the Asian-Pacific summer monsoon, J. Climate, 15, 386-398, https://doi.org/10.1175/15200442(2002)015<0386:RSOTAP>2.0.CO;2, 2002.
Wu, M.-L. C., Reale, O., Schubert, S. D., Suarez, M. J., and Thorncroft, C. D.: African easterly jet: Barotropic instability, waves, and cyclogenesis, J. Climate, 25, 1489-1510, https://doi.org/10.1175/2011JCLI4241.1, 2012.

Zhao, Y., Braconnot, P., Marti, O., Harrison, S., Hewitt, C., Kitoh, A., Liu, Z., Mikolajewicz, U., Otto-Bliesner, B., and Weber, S.: A multi-model analysis of the role of the ocean on the African and Indian monsoon during the mid-Holocene, Clim. Dynam., 25, 777-800, 2005.

Zielinski, G., Mayewski, P., Meeker, L., Whitlow, S., and Twickler, M.: A 110,000-Yr Record of Explosive Volcanism from the GISP2 (Greenland) Ice Core, Quaternary Res., 45, 109-118, https://doi.org/10.1006/qres.1996.0013, 1996. 